(2) norden 



\section{Acid neutralization capacity of waste - specification of requirement stated in landfill regulations}

Margareta Wahlström, Jutta Laine-Ylijoki, Tommi Kaartinen, Ole Hjelmar och David Bendz 


\section{Acid neutralization capacity of waste - specification of}

requirement stated in landfill regulations

TemaNord 2009:580

(C) Nordic Council of Ministers, Copenhagen 2009

ISBN 978-92-893-1942-3

This publication can be ordered on www.norden.org/order. Other Nordic publications are available at www.norden.org/publications

\section{Nordic Council of Ministers}

Store Strandstræde 18

DK-1255 Copenhagen K

Phone (+45) 33960200

Fax (+45) 33960202

\section{www.norden.org}

\section{Nordic Council}

Store Strandstræde 18

DK-1255 Copenhagen K

Phone (+45) 33960400

Fax (+45) 33111870

\section{Nordic co-operation}

Nordic cooperation is one of the world's most extensive forms of regional collaboration, involving Denmark, Finland, Iceland, Norway, Sweden, and three autonomous areas: the Faroe Islands, Greenland, and Åland.

Nordic cooperation has firm traditions in politics, the economy, and culture. It plays an important rol in European and international collaboration, and aims at creating a strong Nordic community in a strong Europe.

Nordic cooperation seeks to safeguard Nordic and regional interests and principles in the global community. Common Nordic values help the region solidify its position as one of the world's most innovative and competitive. 


\section{Content}

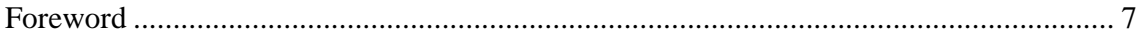

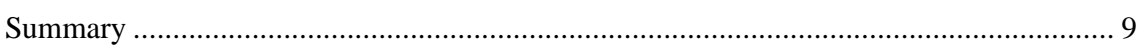

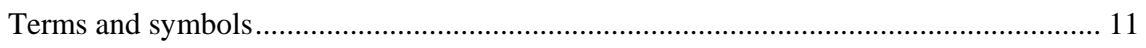

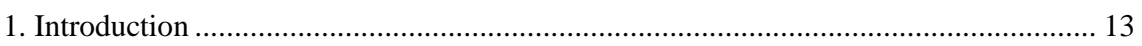

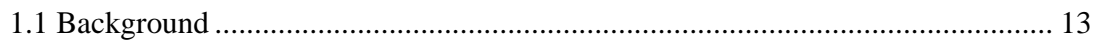

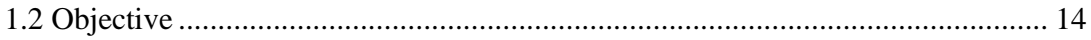

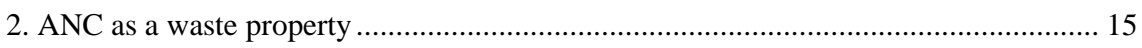

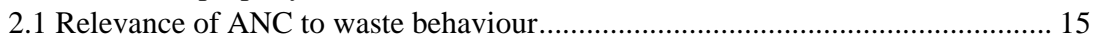

2.2 ANC as a parameter .......................................................................................... 18

2.3 Waste-specific properties affecting ANC ............................................................. 19

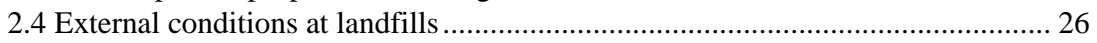

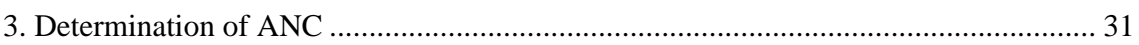

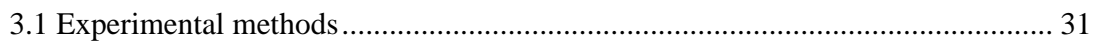

3.2 Other supplementary approaches....................................................................... 34

3.3 Practical aspects of testing (observations, challenges) .......................................... 35

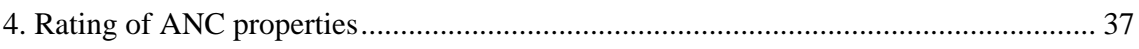

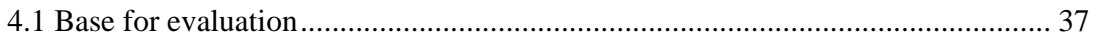

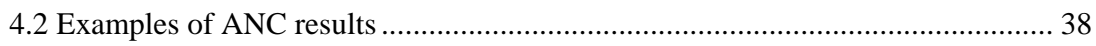

4.3 Correlation of results with composition ............................................................. 42

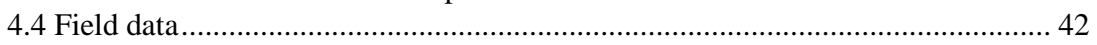

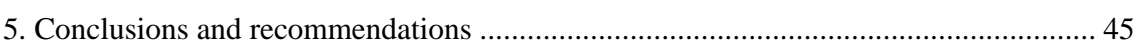

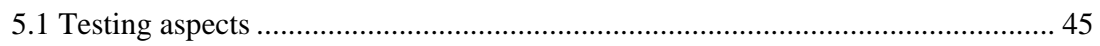

5.2 Evaluation of ANC for waste acceptance ............................................................ 45

5.3 Critical wastes and waste properties with respect to ANC ................................... 47

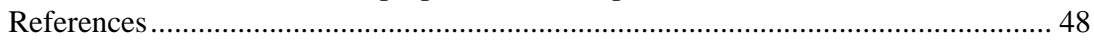

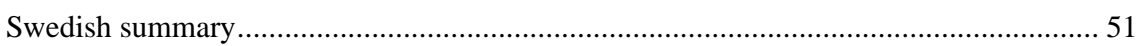





\section{Foreword}

This document is the final report on the project entitled: "Acid neutralization capacity of waste - specification of requirement stated in landfill regulations" financed by Nordic Council of Ministers, PA-Landfill group. The project was initiated in October 2008 and was finished in April 2009.

The background for this project is the EU Council Decision 2003/33/EC establishing criteria and procedures for the acceptance of waste at landfills pursuant to the Landfill Directive 1999/31/EC. The Council Decision sets requirements for evaluation of the acid neutralization capacity (ANC) of waste to be disposed at landfills for hazardous wastes and for hazardous waste to be disposed at non-hazardous landfill and also for non-hazardous waste disposed in the same cell as stable nonreactive hazardous waste.

The main objective of the project was to give guidelines for interpretation of the ANC property in evaluation of waste acceptance at landfills.

The project work has been followed by a Steering Group consisting of the members of the Nordic Landfill Group:

- Denmark: Jørgen G. Hansen

- Faroe Islands: Eyð Eidesgaard

- Finland: Ari Seppänen (Chairman)

- Iceland: Gudmundur Bjarki Ingvarsson

- Norway: Rita Vigdis Hansen and Anette Rognan

- Sweden: Erika Nygren and Carl Mikael Strauss

Isabelle Thélin, Statens Forurensningstilsyn, Norway, has been projectmanager from the Nordic Council of Ministers.

The project was carried out by VTT from Finland. The project group consisted of the following persons:

$\begin{array}{ll}\text { Margareta Wahlström } & \text { VTT, Finland (project manager) } \\ \text { Tommi Kaartinen } & \text { VTT } \\ \text { Jutta Laine-Ylijoki } & \text { VTT } \\ \text { Pekka Kronqvist } & \text { VTT } \\ \text { Ole Hjelmar } & \text { DHI } \\ \text { David Bendz } & \text { SGI } \\ \text { Ola Wik } & \text { SGI }\end{array}$





\section{Summary}

The overall aim of the EU landfill regulation is the safe disposal of waste in the long term. The Council Decision 2003/33/EC related to the EU Landfill Directive 1999/31/EC sets requirements on the collection of basic information on waste characteristics to improve the understanding of the behaviour of waste in landfills and to assess the requirements for treatment. The determination of the acid neutralization capacity (ANC) of waste has been included as a requirement in the Council Decision in order to provide information on the long-term behaviour of the waste. The ANC-property gives information on the behaviour of the waste material itself, but it is also important for understanding the influence on the surroundings at a landfill (e.g. due to interaction with other materials or landfill leachate).

The overall waste body at a landfill needs to become and remain roughly neutral ( $\mathrm{pH} \mathrm{7-8)} \mathrm{in} \mathrm{order} \mathrm{to} \mathrm{avoid} \mathrm{any} \mathrm{long-term} \mathrm{adverse} \mathrm{effects}$ in the landfill waste body or in the environment of a landfill. Adverse effects, such as increase in the leachability of metals and organic substances in the waste body and negative impact on the functionality of landfill barriers, may be caused both by low or high $\mathrm{pH}$ values in waste leachate. Acidic or alkaline leachate occurs when the neutralization effects (e.g. minerals) are not able to neutralize acid or base generated by reactions in the waste (e.g. sulphide oxidation, anaerobic or aerobic digestion of organics) or by external effects (e.g. acid rain and carbonation due to the reaction of atmospheric carbon dioxide with especially calcium hydroxide).

This report gives background information on the importance of the ANC property and its links to safe disposal. The aim of this report is also to provide guidance on interpretation of the results. The report also includes a review of critical waste and waste properties with respect to ANC. The ANC property cannot be evaluated alone. The evaluation of a given neutralization potential depends on the longer term conditions under which the waste will be placed and on whether the potential acidification is inherent in the waste (i.e. whether it has an acid-producing capacity) or whether the acidification will occur only through external influences. The report especially highlights the importance of taking into account the carbonation process in the evaluation of the long-term behaviour of waste (e.g. slags, fly ashes from energy production). 



\section{Terms and symbols}

\begin{tabular}{|c|c|}
\hline ABA (acid base accounting) test & See static test \\
\hline AMD & $\begin{array}{l}\text { Acid Mine Drainage, acid drainage stemming from an open pit, } \\
\text { underground mining operations, waste-rock or tailings facilities that } \\
\text { contain free sulphuric acid and dissolved metals sulphates salts, } \\
\text { resulting from the oxidation of contained sulphide minerals or addi- } \\
\text { tives to the process }\end{array}$ \\
\hline ANC & Acid neutralization capacity \\
\hline AP & Acid potential \\
\hline ARD & Acid Rock Drainage (see AMD) \\
\hline CEN & European Committee for Standardization \\
\hline DOC & Dissolved organic carbon \\
\hline EN & European norm developed by CEN \\
\hline L/S & Ratio between the amount of liquid $(\mathrm{L})$ and of solid $(\mathrm{S})$ in the test \\
\hline MSWI & Municipal solid waste incinerator \\
\hline NNP & Net neutralization potential \\
\hline NP & Neutralization potential \\
\hline NPR & Neutralization potential ratio \\
\hline $\mathrm{pH}$-dependence test & $\begin{array}{l}\text { Test for determination of influence of } \mathrm{pH} \text { on the leachability of inor- } \\
\text { ganic constituents from a solid waste material }\end{array}$ \\
\hline Sobek test & A static test developed by Sobek \\
\hline Stabilized/solidified process & $\begin{array}{l}\text { Stabilization processes change the dangerousness of the constitu- } \\
\text { ents in the waste and thus transform hazardous waste into non- } \\
\text { hazardous waste. Solidification processes only change the physical } \\
\text { state of the waste (e.g. liquid into solid) by using additives without } \\
\text { changing the chemical properties of the } \\
\text { waste. }\end{array}$ \\
\hline Static test & $\begin{array}{l}\text { Screening test for determination of acid and neutralization potential in } \\
\text { sulphidic waste }\end{array}$ \\
\hline TS & Technical specification developed by CEN (test method not validated) \\
\hline
\end{tabular}





\section{Introduction}

\subsection{Background}

The overall aim of the EU landfill regulation is the safe disposal of waste in the long term. The Council Decision 2003/33/EC related to the EU Landfill Directive 1999/31/EC sets requirements on the collection of basic information on waste characteristics to improve the understanding of the behaviour of waste in landfills and to assess the requirements for treatment. The determination of the acid neutralization capacity (ANC) of waste has been included as a requirement in the Council Decision in order to provide information on the long-term behaviour of the waste. The ANC-property gives information on the behaviour of the waste material itself, but it is also important for understanding the influence on the surroundings at a landfill (e.g. due to interaction with other materials or landfill leachate).

The Council Decision requires an evaluation of the acid neutralization capacity for waste to be disposed at landfills for hazardous waste and for non-hazardous waste landfills that also accept stable, non-reactive hazardous waste. Actually, this property is important for all waste to be disposed at landfills, including also waste utilization. Especially in cases where different types of wastes are landfilled together, the influence of leachate from other disposed wastes needs to be taken into account.

This parameter was not earlier required for wastes, which means that only limited knowledge of test interpretation was available when this parameter was introduced. Therefore, no guideline for the test result interpretation and no criteria for waste acceptance are given in the Council Decision. Practically, this means that implementing the ANC requirement is difficult for local authorities.

The European standardization organization CEN has developed a test method for ANC, which is almost equivalent to the $\mathrm{pH}$-dependence test procedure especially developed for evaluation of metal leaching behaviour. Specific guidance is needed on the $\mathrm{pH}$ range to be covered in testing. Furthermore, for wastes from the extractive industry (in some cases the same wastes might also fall under the landfill directive) information on the acid generation behaviour will be required and tools for the evaluation of acid potential and neutralization potential are under preparation in CEN. 


\subsection{Objective}

The aim of the project is to provide guidance on how to measure and evaluate the ANC of waste. A proposal for the approach in interpretation of ANC is presented. The results from this project can be used in the development of national guidelines for implementation of the EU Council Decision.

The project will include the following aspects:

- information on importance of the ANC property and its links to safe disposal (what is measured and how information of this property can be used)

- guidance on interpretation of results and guidance on how to take this parameter into account in the evaluation of acceptance of waste at landfills, including information on its consequences for waste acceptance on landfills

- review of test results from Nordic waste materials, the applicability of ANC method in this context, a recommendation for a simplified procedure in some cases (e.g. when there is a need to cover the whole $\mathrm{pH}$ range, how to narrow the test procedure to a critical $\mathrm{pH}$ range, when it is possible to rely on existing data for similar material).

The target group for this report includes all the stakeholders involved such as the authorities, regulators, waste producers, consultants, and testing laboratories. 


\section{ANC as a waste property}

\subsection{Relevance of ANC to waste behaviour}

The overall waste body at a landfill needs to become and remain roughly neutral (pH 7-8) in order to avoid any long-term adverse effects in the landfill waste body or in the environment of a landfill. Acidic or alkaline leachate occurs when the neutralization effects (e.g. minerals) are not able to neutralize acid or base generated by reactions in waste (e.g. sulphide oxidation, anaerobic or aerobic digestion of organics) or by external effects (e.g. acid rain, carbonation due to reaction with atmospheric carbon dioxide). Adverse effects (e.g. increase in metals and organics leachability, negative impact on landfill barriers) may be caused both by low or high $\mathrm{pH}$ values in waste leachate.

The buffer capacity of a waste can be measured and expressed in terms of the so-called acid neutralization capacity (ANC). It is usually not possible to assess the buffering capacity of an entire landfill and therefore the $\mathrm{pH}$ stability of a landfill is evaluated through the testing of single waste materials and taking into account the actual landfill conditions in the test interpretation (e.g. waste streams, landfill construction, management etc). Therefore, the ANC property cannot be evaluated alone. For evaluation of risk related to specific ANC data, information is needed on the waste properties that are critical to $\mathrm{pH}$ behaviour.

\subsubsection{Leaching of inorganic substances}

Leaching of most elements, especially metals, is affected by $\mathrm{pH}$. The ability of waste materials to maintain neutral or slightly alkaline $\mathrm{pH}$ levels in the long term is very important, because leachability usually has a minimum within a specific $\mathrm{pH}$ range and increases manifold with a decrease or increase in $\mathrm{pH}$. For example, many cationic metals, e.g. $\mathrm{Cd}, \mathrm{Pb}$, and $\mathrm{Zn}$ show increasing leaching at low $\mathrm{pH}$. For elements where the leaching may be controlled by amphoteric oxides, typically $\mathrm{Pb}$ and $\mathrm{Zn}$ show increasing leaching both at low and high $\mathrm{pH}$. Some elements, e.g. those forming oxyanions such as As, Cr, Mo, Se, Sb may show an increased leachability at neutral or higher $\mathrm{pH}$ values. A pH of 8-9 (within the buffering of a carbonate system) is commonly regarded as favourable for a low leaching of most metals. The buffer capacity of the waste hence influences the ability of the waste to remain at stable leachability for most metals.

Geochemical modelling is often used to understand the long-term behaviour of waste at a landfill. The aim is to understand the solid phases in waste materials controlling the leaching behaviour and through this in- 
formation identify critical landfill conditions. Important input data in geochemical testing are the results from a $\mathrm{pH}$-dependence test in which the leachability of metals is studied at selected $\mathrm{pH}$ values.

Typical curves for inorganic substances, particularly salts and metals, describing the $\mathrm{pH}$-dependence release are presented in Figure 1.
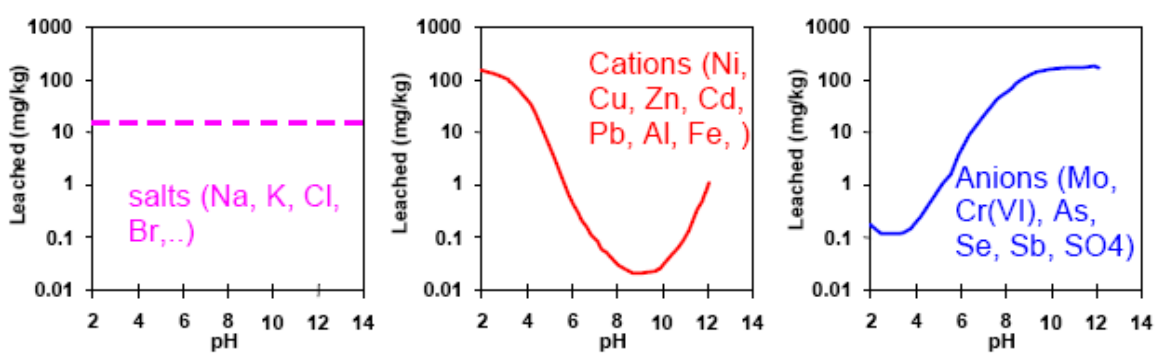

Figure 1. Leaching behaviour dependence of pH (van der Sloot et al 2008).

The solubility of metals depends on their chemical form. The minimum solubility of some selected metal hydroxides is shown in Table 1 (ref. GARD 2009). Many metals have an amphoteric property, with decreasing solubility up to a threshold $\mathrm{pH}$, above which the metal solubility increases again because of the formation of soluble complex. Table 1 clearly shows the difficulties in finding a safe $\mathrm{pH}$ range for waste materials containing several metals.

Table 1. Theoretical minimum metal hydroxide solubility $\mathrm{pH}$ for selected metals (GARD 2009)

\begin{tabular}{lc}
\hline Metal & pH corresponding to minimum metal hydroxide solubility in water \\
\hline Antimony, $\mathrm{Sb}^{2+}$ & 4.2 \\
Ferric iron, $\mathrm{Fe}^{3+}$ & 3.5 \\
Aluminium, $\mathrm{Al}^{3+}$ & 4.5 \\
Lead, $\mathrm{Pb}^{2+}$ & 6.5 \\
Copper, Cu2+ & 7.0 \\
Ferrous iron, $\mathrm{Fe}^{2+}$ & 8.0 \\
Zinc, $\mathrm{Zn}^{2+}$ & 8.5 \\
Nickel, $\mathrm{Ni}^{2+}$ & 9.3 \\
Cadmium, $\mathrm{Cd}^{2+}$ & 10.0 \\
Manganese, $\mathrm{Mn}^{2+}$ & 10.6 \\
\hline
\end{tabular}

\subsubsection{Connections to DOC leaching}

Leachate from wastes, particularly from organic waste, often contains some level of dissolved organic carbon (DOC). For several waste materials, leaching of DOC is strongly linked to the $\mathrm{pH}$ of the waste (Fig. 2). The limit values for dissolved total organic carbon (DOC) are given in the Council Decision for wastes to be disposed at selected landfill categories, i.e. landfills for inert waste, hazardous waste, and for non-hazardous waste landfills also accepting stable, non-reactive hazardous waste. The reason for this is the ability of DOC to increase the leachability of some harmful metals (copper, nickel) and organic substances in the waste body 
(Meima et al. 1999). In addition, DOC and particulate organic matter in run-off-water from the landfill increases the oxygen consumption in the surface water, and may cause reducing conditions which may have an impact on the ecosystem and potentially increase the solubility of metals.

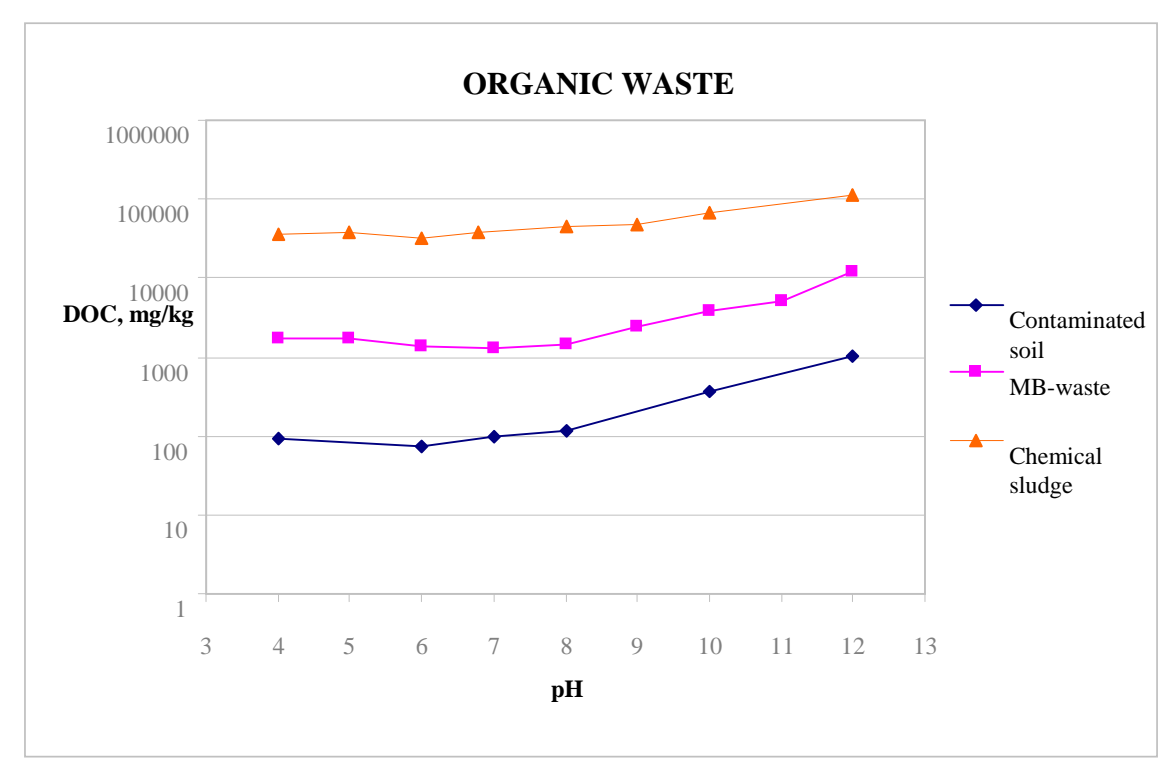

Figure 2. The correlation between eluate $\mathrm{pH}$ and DOC concentration in test eluate for contaminated soil, mechanically and biologically treated MSW and sludge. Change in DOC concentration from $\mathrm{pH} 7$ to $\mathrm{pH} 12$ can be 10-fold.

In particular, the relation between the leaching of copper and DOC have been intensively studied for bottom ash from municipal solid waste incineration (MSWI). In MSWI bottom ash leachates dissolved copper has been found to be $95-100 \%$ organically bound. It has been proved that the leaching of copper from bottom ash is primarily controlled by the availability of organic ligands in the ash. In the absence of DOC the predicted $\mathrm{Cu}$ leaching would have been 2-3 orders of magnitude lower (Meima et al. 1999). For antimony the enhanced leaching from MSWI bottom ash in the presence of dissolved organic carbon is also reported (Kaartinen, 2004).

DOC leaching can also be seen as parameter to reflect the degradability of the material and the organic carbon related to the biodegradability, which are of greatest concern for waste acceptance to a landfill. It can therefore be used for the characterization of carbon compounds available for biodegradation in leachates. In other words, the more DOC that is released, the more 'bio-reactive' is the waste (Laine-Ylijoki et al. 2004). A chemical degradation of organic matter also occurs both in alkaline and acid conditions and therefore the DOC release reflecting the biodegradation potential of the waste material is preferably checked in a neutral $\mathrm{pH}$ range. However, more information on the relationships between eluate DOC and biodegradation is still needed. 


\subsubsection{Cement stabilization processes}

The stabilization/solidification processes with Portland cement or hydraulic binders are often used as treatment methods for wastes containing high amounts of metal. The $\mathrm{pH}$ of a solidified product is important because the solubility of contaminants is often $\mathrm{pH}$-dependent, and especially because the physical matrix is dissolved and weakened by acidic conditions (the solid matrix will disintegrate at $\mathrm{pH}<9$ ). Portland cement will tend to result in high $\mathrm{pH}$ and high ANC, while replacement of cement with pozzolanic binders will result in lower ANC. (Eglinton 1998)

ANC properties are important for the assessment of the long-term properties of cement-stabilized waste. The focus is to evaluate the development of a $\mathrm{pH}$ front (carbonation) with potential consequences for changes in leaching behaviour or durability of cement-based materials. Carbonation may lead to a loss of structural integrity of cement-stabilized waste. Although $\mathrm{pH}<9$ is common in the natural environment, the prediction of leachability at lower $\mathrm{pH}$ values is usually of little importance for cement-solidified products. (Stegemann 2002)

However, the outer surface of the cement-stabilized wastes may undergo atmospheric carbonation relatively quickly (van der Sloot et al 2007). Therefore the surface leaching from cement-stabilized materials at neutral $\mathrm{pH}$ requires attention (see 2.4.1).

\subsection{ANC as a parameter}

The acid neutralization capacity (ANC) of waste is a measure for the overall buffering capacity against the change in $\mathrm{pH}$ which might stem from reactions in the waste materials themselves or external conditions. In both cases, this leads to a change of $\mathrm{pH}$ in landfill leachate (e.g. through formation of acid). ANC measurements cover both the acid neutralization capacity of the waste solution and the solids present.

The term "alkalinity" is often incorrectly used for ANC. Alkalinity means strictly the ability of a solution to neutralize acids to the equivalence points of carbonate or bicarbonate (Stumm and Morgan, 1995). According to a more general definition given in the IPCC report (2001), alkalinity is a measure of the capacity of water to neutralize acids.

There are different waste test methods for determination of the acid neutralization capacity of a waste material. The ANC is generally determined through titration to a selected $\mathrm{pH}$ value. The property is expressed in $\mathrm{mol} / \mathrm{kg}$. In waste characterization, ANC testing not only covers acid neutralization capacity but also base neutralization capacity (BNC). Such ANC/BNC characterization test data can be used to assess the amount of acid (as $\mathrm{H}+$ ) or base $\left(\mathrm{OH}^{-}\right)$needed to reach a given final $\mathrm{pH}$ in a waste.

The data can also be used to assess the effect of external influences, such as carbonation and oxidation (acid production resulting from sul- 
phide oxidation in sulphide-containing waste, e.g. mining waste or acidic sulphate soils) on the $\mathrm{pH}$ of a waste. The external influences need to be calculated in the same units to allow comparison, and therefore carbonation would have to be assessed through the volume of gas, concentration of carbon dioxide $\left(\mathrm{CO}_{2}\right)$, and conversion to corresponding moles of $\mathrm{H}+$ neutralizing capacity.

The terms often used in connection with acid neutralization capacity are collated in Table 2.

Table 2. Terms used in different references.

\begin{tabular}{|c|c|c|c|}
\hline Matrix & Term & Reference & Definition \\
\hline $\begin{array}{l}\text { Waste } \\
\text { (generally) }\end{array}$ & $\begin{array}{l}\text { Acid or base } \\
\text { neutralization } \\
\text { capacity (ANC, } \\
\text { BNC) }\end{array}$ & $\begin{array}{l}\text { prCEN/TS 15364: Char- } \\
\text { acterization of waste - } \\
\text { Leaching behaviour tests } \\
\text { - Acid and } \\
\text { base neutralization } \\
\text { capacity test }\end{array}$ & $\begin{array}{l}\text { The acid and/or base neu- } \\
\text { tralization capacity of a } \\
\text { material }\end{array}$ \\
\hline Extractive waste & Acid potential (AP) & $\begin{array}{l}\text { prEN 15875: Characteri- } \\
\text { zation of waste - Static } \\
\text { test for determination of } \\
\text { acid potential of sulphidic } \\
\text { waste }\end{array}$ & $\begin{array}{l}\text { The maximum potential acid } \\
\text { generation from a sample } \\
\text { assuming that all sulphur } \\
\text { occurs as pyrite and that } \\
\text { acidity will result from its } \\
\text { complete oxidation }\end{array}$ \\
\hline Extractive waste & $\begin{array}{l}\text { Neutralization } \\
\text { potential (NP) }\end{array}$ & See above & $\begin{array}{l}\text { The capacity of a sample to } \\
\text { neutralize the generated } \\
\text { acidity }\end{array}$ \\
\hline Extractive waste & $\begin{array}{l}\text { Net neutralization } \\
\text { potential (NNP) }\end{array}$ & See above & $\begin{array}{l}\text { Difference of acid potential } \\
\text { and neutralization potential } \\
\text { NNP = NP - AP }\end{array}$ \\
\hline Extractive waste & $\begin{array}{l}\text { Neutralization } \\
\text { potential ratio } \\
\text { (NPR) }\end{array}$ & See above & $\begin{array}{l}\text { Ratio of neutralization poten- } \\
\text { tial and acid potential NPR = } \\
\text { NP / AP }\end{array}$ \\
\hline Soil - liming & Liming effects & $\begin{array}{l}\text { ISO 10693: Soil quality - } \\
\text { determination of carbon- } \\
\text { ate content - Volumetric } \\
\text { method }\end{array}$ & \\
\hline $\begin{array}{l}\text { Cement-stabilized } \\
\text { material }\end{array}$ & $\begin{array}{l}\text { Acid neutralization } \\
\text { capacity (ANC) }\end{array}$ & Stegemann, 2002 & $\begin{array}{l}\text { The ability of a solidified } \\
\text { product to neutralize acid }\end{array}$ \\
\hline
\end{tabular}

\subsection{Waste-specific properties affecting ANC}

In the following sections, the material specific properties (e.g. content of neutralization minerals, sulphur species and organic matter content) influencing the $\mathrm{pH}$ change are discussed. In the long term, it is also likely that waste material-specific properties may change owing to high solubility (depletion) of the compounds responsible for the neutralization potential of the waste. For alkaline waste materials (e.g. APC residues) containing soluble hydroxides in particular, the depletion in the long term 
will probably be more important than the neutralization potential of the minerals (Astrup et al. 2006).

\subsubsection{Waste composition}

Waste matrices may contain different minerals (neutralizing minerals) that consume hydrogen ions. The neutralization reactions of acids are typically associated with the presence of basic calcium or magnesium compounds $\left(\mathrm{Ca}(\mathrm{OH})_{2}, \mathrm{MgCO}_{3}\right.$, etc.), but also aluminium and silicate compounds may be of importance.

Carbonates such as calcite $\left(\mathrm{CaCO}_{3}\right)$ are typically known as having a high neutralization capacity. Carbonates can react and neutralize acids quickly (within minutes to seconds), and often dictate the $\mathrm{pH}$ of calcitecontaining waste materials. Other minerals (e.g. Feldspar group: (Ca, Na) $\left.\mathrm{Al}(\mathrm{Si}, \mathrm{Al})_{3} \mathrm{O}_{8}\right)$ have much slower reaction rates, but they may also be important in neutralizing acidic leachate in the long term. The reactivity of aluminium and silicate compounds depends on the $\mathrm{pH}$.

Two basic neutralization reactions for calcite:

$$
\begin{aligned}
& \mathrm{CaCO}_{3}+2 \mathrm{H}+\rightarrow \mathrm{Ca}^{2+}+\mathrm{H}_{2} \mathrm{CO}_{3} \\
& \mathrm{CaCO}_{3}+\mathrm{H}+\rightarrow \mathrm{Ca}^{2+}+\mathrm{HCO}_{3}
\end{aligned}
$$

The theoretical neutralization potential NP of carbonate can be calculated and expressed as $\mathrm{H}+$ content in $\mathrm{mol} / \mathrm{kg}$. NP expressed as $\mathrm{H}+$ content in $\mathrm{mol} / \mathrm{kg}$ is calculated from the inorganic carbon content $\mathrm{w}\left(\mathrm{CO}_{3}{ }^{2-}-\mathrm{C}\right)$ expressed as mass fraction in \% by dividing by the molar mass of carbon $\mathrm{M}(\mathrm{C})$ and multiplying by 10 (conversion of mass fraction to $\mathrm{mol} / \mathrm{kg}$ ) and again multiplying by 2 (one mole of carbonate is equivalent to 2 moles of $\mathrm{H}^{+}$):

$$
N P=2 \cdot 10 \cdot \frac{w\left(\mathrm{CO}_{3}{ }^{2-}-C\right)}{M(C)}
$$

where

$\mathrm{w}\left(\mathrm{CO}_{3}{ }^{2-}-\mathrm{C}\right) \quad$ is the carbonate content expressed as a mass fraction in $\% \mathrm{w}(\mathrm{C})$

M is the molar mass of carbon $\mathrm{M}(\mathrm{C})$

This can be simplified when $\mathrm{M}(\mathrm{C})=12 \mathrm{~g} / \mathrm{mol}$ is inserted to be (2):

$$
N P=1,666 \cdot w\left(\mathrm{CO}_{3}{ }^{2-}-C\right)
$$


Table 3 illustrates the relative mineral reactivity of frequently appearing minerals. Calcite is also often used as a reference in evaluation of the neutralization capacity of mine wastes and industrial wastes. However, silicates also need to be considered. Practically only the three first mentioned mineral groups are reported to have any practical meaning in the neutralization of acids in mine wastes (Kwong 1993).

Table 4 also shows the buffering $\mathrm{pH}$ for some minerals and some indicative NP values. As can be seen from the table, the carbonate minerals generate significantly more neutralization potential than the silicate minerals and they also buffer at higher values. The NP values are dependent on the test method used (test conditions, grain size).

Table 3. Relative mineral reactivity (modified from Sverdrup, 1990 and Kwong, 1993)

\begin{tabular}{|c|c|c|}
\hline Mineral groups & Typical minerals (examples) & $\begin{array}{r}\text { Relative } \\
\text { reactivity } \\
\text { at } \mathrm{pH} 5\end{array}$ \\
\hline Dissolving & $\begin{array}{l}\text { Calcite } \mathrm{CaCO}_{3} \text {, Aragonite } \mathrm{CaCO}_{3} \text {, Dolomite } \mathrm{CaMg}\left(\mathrm{CO}_{3}\right)_{2} \text {, } \\
\text { Magnesite } \mathrm{MgCO}_{3} \text {, Brucite } \mathrm{Mg}(\mathrm{OH})_{2}\end{array}$ & 1.0 \\
\hline Fast weathering & $\begin{array}{l}\text { Anorthite } \mathrm{CaAl}_{2} \mathrm{Si}_{2} \mathrm{O}_{8} \text {, nepheline, olivine1 (Mg,Fe) } \\
{ }_{2} \mathrm{SiO}_{4} \mathrm{Mg}_{2} \mathrm{SiO}_{4} \text {, garnet, jadeite, leucite, spodumene, } \\
\text { diopside, wollastonite } \mathrm{CaSiO}_{3}\end{array}$ & 0.6 \\
\hline Intermediate weathering & $\begin{array}{l}\text { Epidote } \mathrm{Ca}_{2}(\mathrm{Fe}, \mathrm{Al}) \mathrm{Al}_{2}\left(\mathrm{SiO}_{4}\right)\left(\mathrm{Si}_{2} \mathrm{O}_{7}\right) \mathrm{O}(\mathrm{OH}) \text {, Zoisite, Enstatite2, } \\
\text { Hypersthene, Augite, Hedenbergite, Hornblende, Glaucophane, } \\
\text { Tremolite, Actinolite, Anthophyllite, Serpentine, Chrysotile, Talc, } \\
\text { Chlorite, Biotite }\end{array}$ & 0.4 \\
\hline Slow weathering & $\begin{array}{l}\text { Albite } \mathrm{NaAlSi}_{3} \mathrm{O}_{8} \text {, Oligoclase }(\mathrm{Na}, \mathrm{Ca})(\mathrm{Al}, \mathrm{Si}) \mathrm{AlSi}_{2} \mathrm{O}_{8} \text {, Montmo- } \\
\text { rillonite }(\mathrm{Na}, \mathrm{Ca}) 0.33(\mathrm{Al}, \mathrm{Mg})_{2}\left(\mathrm{Si}_{4} \mathrm{O}_{10}\right)(\mathrm{OH})_{2} \cdot \mathrm{nH}_{2} \mathrm{O} \text {, Gibbsite } \\
\mathrm{Al}(\mathrm{OH})_{3}, \mathrm{Kaolinite} \mathrm{Al}_{2} \mathrm{Si}_{2} \mathrm{O}_{5}(\mathrm{OH})_{4}(=\text { clay })\end{array}$ & 0.02 \\
\hline Very slow weathering & K-feldspar KalSi ${ }_{3} \mathrm{O}_{8}$, Muscovite $\mathrm{KAl}_{2}\left(\mathrm{AlSi}_{3} \mathrm{O}_{10}\right)(\mathrm{OH})_{2}$ & 0.01 \\
\hline Inert & Quartz $\mathrm{SiO}_{2}$, Rutile $\mathrm{TiO}_{2}$, Zircon $\mathrm{ZrSiO}_{4}$ & 0.004 \\
\hline
\end{tabular}


Table 4. Typical NP-values and pH-buffering ranges from some minerals (modified from GARD guide 2009, Jambor 2005)

\begin{tabular}{|c|c|c|c|}
\hline Group & Formula & $\begin{array}{l}\text { Buffering } \mathrm{pH} \text { - } \\
\text { range }\end{array}$ & $\begin{array}{l}\text { Neutralization } \\
\text { potential range } \\
\text { (indicative)*) } \\
\left(\mathrm{mol} \mathrm{H}^{+} / \mathrm{kg}\right)\end{array}$ \\
\hline Carbonates & & & $10-27$ \\
\hline calcite, aragonite & $\mathrm{CaCO}_{3}$ & $5.5-6.9$ & 20 \\
\hline dolomite & & & 22 \\
\hline siderite & $\mathrm{FeCO}_{3}$ & $5.1-6.0$ & $\begin{array}{l}\text { do not contrib- } \\
\text { ute to NP }\end{array}$ \\
\hline malachite & $\mathrm{Cu}_{2} \mathrm{CO}_{3}(\mathrm{OH})_{2}$ & $5.1-6.0$ & \\
\hline \multicolumn{4}{|l|}{ Oxides } \\
\hline gibbsite & $\mathrm{Al}(\mathrm{OH})_{3}$ & $3.7-4.3$ & \\
\hline limonite/goethite & $\mathrm{FeOOH}$ & $3.0-3.7$ & \\
\hline ferrihydrite & $\mathrm{Fe}(\mathrm{OH})_{3}$ & $2.8-3.0$ & \\
\hline Jarosite & $\mathrm{KFe}_{3}\left(\mathrm{SO}_{4}\right)_{2}(\mathrm{OH})_{6}$ & $1.7-2.0$ & \\
\hline Aluminosilicates & & $0.5-1.5$ & \\
\hline \multicolumn{4}{|l|}{ Feldspar Group } \\
\hline K-feldspar & $(\mathrm{K}, \mathrm{Na}) \mathrm{AlSi}_{3} \mathrm{O}_{8}$ & & $0.01-0,03$ \\
\hline anorthite(An51- An100) & $\mathrm{CaAl}_{2} \mathrm{Si}_{2} \mathrm{O}_{8}$ & & $0,1-0,25$ \\
\hline \multicolumn{4}{|l|}{ Mica Group } \\
\hline muscovite & $\mathrm{KAl}_{2}\left(\mathrm{AlSi}_{3} \mathrm{O}_{10}\right)(\mathrm{OH})_{2}$ & & 0.006 \\
\hline biotite & $\mathrm{K}(\mathrm{Mg}, \mathrm{Fe})_{3}\left(\mathrm{AlSi}_{3} \mathrm{O}_{10}\right)(\mathrm{OH})_{2}$ & & $0,05-0,2$ \\
\hline Chlorite Group & $(\mathrm{Mg}, \mathrm{Fe}, \mathrm{Al})_{6}(\mathrm{Al}, \mathrm{Si})_{4} \mathrm{O}_{10}(\mathrm{OH})_{8}$ & & $0.02-0,4$ \\
\hline Clay Group & $(\mathrm{Me})(\mathrm{Si}, \mathrm{Al})_{4} \mathrm{O}_{10}(\mathrm{OH})_{2}$ & & $-0,05-0,6$ \\
\hline Apatite Group & $\mathrm{Ca}_{5}(\mathrm{PO} 4)_{3}(\mathrm{~F}, \mathrm{Cl}, \mathrm{OH})$ & & $0,05-0,2$ \\
\hline \multicolumn{4}{|l|}{ Miscellaneous } \\
\hline talc & $\mathrm{Mg}_{3} \mathrm{Si}_{4} \mathrm{O}_{10}(\mathrm{OH})_{2}$ & & 0,03 \\
\hline serpentine & $\mathrm{Mg}_{6} \mathrm{Si}_{4} \mathrm{O}_{10}(\mathrm{OH})_{8}$ & & $0,3-2$ \\
\hline epidote & $\mathrm{Ca}_{2}(\mathrm{Al}, \mathrm{Fe})_{3} \mathrm{Si}_{3} \mathrm{O}_{12}(\mathrm{OH})$ & & $0,02-0,06$ \\
\hline wollastonite & $\mathrm{CaSiO}_{3}$ & & 9 \\
\hline
\end{tabular}

*) results mainly through Sobek test (Note: often a more aggressive test than the static test prEN 15875 described in section 3)

Lawrence \& Scheske (1997) proposed a simple procedure for the calculation of the effective NP based on mineralogical composition and the relative reactivities of component minerals (see Table 3). When the mineralogy of a waste is known, the contribution of each mineral in a waste to the NP value can theoretically be estimated by adding together the weighted NP values for each component mineral (see equation 3).

$$
N P\left(\mathrm{molH}^{+} / \mathrm{kg}\right)=\frac{w-\%(\min )}{100} \cdot \frac{M_{\left(\mathrm{CaCO}_{3}\right)}}{M_{(\min )}} \cdot f \cdot R
$$

where

$\mathrm{w}-\%$ (min) is the mineral content in the waste expressed as a mass fraction in \%

$\mathrm{M}_{\min } \quad$ is the molar mass of the mineral

$\mathrm{M}_{\mathrm{CaCO} 3} \quad$ is the molar mass of calcite $(\mathrm{M}=100 \mathrm{~g} / \mathrm{mol})$ is the conversion factor for expressing mass fraction in \% to $\mathrm{mol} \mathrm{H}^{+} / \mathrm{kg}(=20)$ 
For example a waste containing $100 \%$ of

- a fast weathering mineral such as anorthite $(\mathrm{M}=277 \mathrm{~g} / \mathrm{mol})$ contributes to a neutralization potential of $4.3 \mathrm{~mol} \mathrm{H}^{+} / \mathrm{kg}$

- an intermediate weathering mineral such as epidote $(\mathrm{M}=483 \mathrm{~g} / \mathrm{mol})$ contributes $1.6 \mathrm{~mol} \mathrm{H}^{+} / \mathrm{kg}$

- a slow weathering mineral such as albite $(\mathrm{M}=263 \mathrm{~g} / \mathrm{mol})$ and gibbsite ( $\mathrm{M}=78 \mathrm{~g} / \mathrm{mol}$ ) contributes $0.15 \mathrm{~mol} \mathrm{H}^{+} / \mathrm{kg}$ and $0.5 \mathrm{~mol} \mathrm{H}^{+} / \mathrm{kg}$, respectively

\subsubsection{Organic matter content}

Organic matter degrades owing to microbial activities. The general process of organic degradation is illustrated in Figure 3.

The breakdown of organic matter in landfill conditions proceeds sequentially from the complex to the simple starting with the hydrolysis of complex particulate matter to simpler polymers like proteins, carbohydrates and lipids which are further hydrolyzed to yield bio-monomers like amino acids, sugars, and high molecular fatty acids. Amino acids and sugars are converted into either intermediate by-products (e.g. propionic, butyric and other volatile acids) or directly fermented to acetic acid. High molecular fatty acids are oxidized to intermediate by-products and hydrogen. Methane and carbon dioxide generation occurs primarily through acetate cleavage. Methane is also produced through carbon dioxide reduction with hydrogen. In a landfill environment, methane generation from the latter route is often limited by the lack of hydrogen which is consumed by sulphate reducers. (El-Fadel et al. 1997)

The organic contents of leachate at a landfill for organic wastes are dependent upon the kind of decomposition conditions (aerobic, anaerobic acetic production or anaerobic methane production). With anaerobic acetic production, soluble and volatile fatty acids are produced. The organic acids produced decrease the $\mathrm{pH}$ in the leachate. In the following methane production phase, these acids are converted to $\mathrm{CO}_{2}$ and $\mathrm{CH}_{4}$ which results in low organic content in the leachate contents. (Ehring, 1983). 


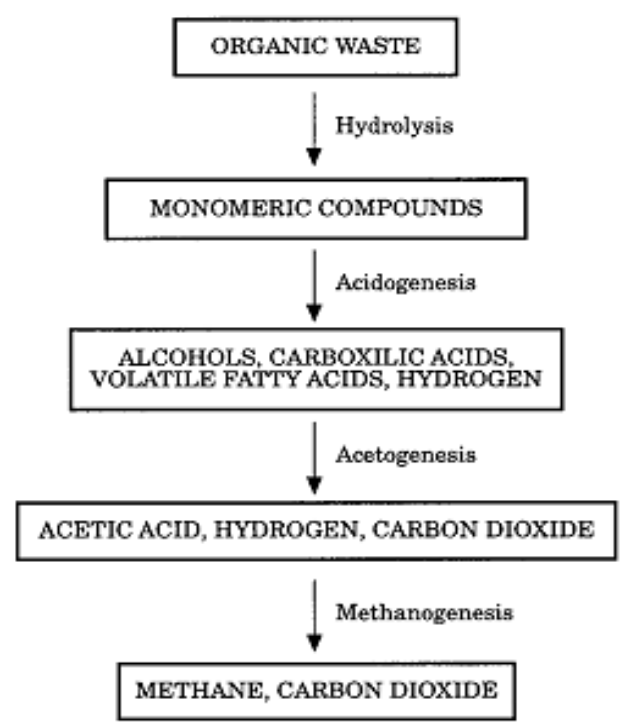

Figure 3. Major degradation steps during the anaerobic decomposition phase. (El-Fadel et al. 1997)

Lower molecular weight DOC is released from the material in significant quantities when it is biodegraded. The solubility of this type of often polar and ionic DOC is relatively unaffected by $\mathrm{pH}$, which explains the plateau in the DOC leaching curve (see Figure 2). For further degraded material (e.g. waste from mechanical biological treatment) the rise in DOC release in the high $\mathrm{pH}$ range results from leaching of high molecular weight DOC (largely humic acid) that is ionized and released in the alkaline $\mathrm{pH}$ range. Higher molecular weight organic matter is also less degradable. The DOC level in the eluate therefore reflects the degree of degradation of a material.

\subsubsection{Sulphur species}

Acid-generating sulphur compounds appear typically in sulphidecontaining wastes from the extractive industry, in marine sediments and in acid sulphate soils. Also slag produced in thermal processes (e.g. blast furnace slag) may contain sulphide compounds. Acid sulphate soil is a particular problem on the west coast of Finland and in some parts of Sweden because it leads to acidic water flows. In this context, acid sulphate soil is only of concern in landfills when disposed or used as construction material in landfills.

Examples of the most common sulphur species which may occur in extractive wastes are collated in Table 5. Inorganic sulphur occurs in extractive wastes mainly as sulphide and sulphate minerals. Pyrite is the most common sulphide mineral commonly thought to generate sulphuric acid. The secondary minerals resulting from sulphide oxidations include soluble sulphates, hydrous sulphates and hydroxysulphates, metal oxides and hy- 
droxides. Some of these secondary minerals may cause additional acidity during their formation (e.g. metal(hydr)oxides) or during the release of the stored acidity (e.g. jarosite). These minerals are highly soluble so they can represent an instantaneous source of acidic sulphate-rich water upon dissolution and hydrolysis, for example the dissolution of jarosite.

In the recently approved Commission Decision 2009/360/EC on "the definition of inert waste" limit values have been given for the content of sulphide sulphur in waste from the extractive industry. Waste to be considered inert must fulfil the following criteria for sulphide sulphur content:

"the waste has a maximum content of sulphide sulphur of $0.1 \%$, or the waste has a maximum content of sulphide sulphur of $1 \%$ and the neutralising potential ratio, defined as the ratio between the neutralising potential and the acid potential, and determined on the basis of a static test prEN 15875 is greater than 3”.

Determination of the acid potential (AP) is based on the following chemical reaction:

$$
\mathrm{FeS}_{2}+15 / 4 \mathrm{O}_{2}+7 / 2 \mathrm{H}_{2} \mathrm{O}->\mathrm{Fe}(\mathrm{OH})_{3}+2 \mathrm{SO}_{4}{ }^{2-}+4 \mathrm{H}^{+}
$$

Accordingly, one mole of pyrite gives 4 moles of $\mathrm{H}^{+}$or - equivalently one mole of sulphur give 2 moles of $\mathrm{H}^{+}$. AP expressed as $\mathrm{H}^{+}$content in $\mathrm{mol} / \mathrm{kg}$ is therefore calculated from the sulphur content expressed as a mass fraction in \% $\mathrm{w}(\mathrm{S})$ by dividing by the molar mass of sulphur $\mathrm{M}(\mathrm{S})$ and multiplying by 10 (conversion of mass fraction in \% to $\mathrm{mol} / \mathrm{kg}$ ) and again multiplying by 2 (one mole of sulphur gives 2 moles of $\mathrm{H}^{+}$):

$$
A P=2 \cdot 10 \cdot \frac{w(S)}{M(S)}
$$

where

$w(S) \quad$ sulphide-sulphur content expressed as mass fraction in \% $M(S) \quad$ molar mass of sulphur

Formula (4) can be simplified when $\mathrm{M}(\mathrm{S})=32 \mathrm{~g} / \mathrm{mol}$ is inserted to be

$$
A P=0,625 \cdot w(S)
$$


Table 5. Examples of sulphur species. (Piantone, 2008)

\begin{tabular}{lll}
\hline Sulphur species & Mineral & Chemical Formula \\
\hline Native Sulphur & Pyrite & $\mathrm{FeS}_{2}$ \\
& Marcasite & $\mathrm{FeS} 2$ \\
& Chalcopyrite & $\mathrm{CuFeS} 2$ \\
& Chalcocite & $\mathrm{Cu} 2 \mathrm{~S}$ \\
Sphalerite & $\mathrm{ZnS}$ \\
Galena & $\mathrm{PbS}$ \\
& Millerite & $\mathrm{NiS}$ \\
& Pyrrhotite & $\mathrm{Fe}(1-\mathrm{x}) \mathrm{S}($ where $0<x<0.2)$ \\
& Arsenopyrite & $\mathrm{FeAsS}$ \\
& Cinnabar & $\mathrm{HgS}$ \\
& Melanterite & $\mathrm{Fe} 2+\mathrm{SO} 4 \circ 7 \mathrm{H} 2 \mathrm{O}$ \\
& Rozenite & $\mathrm{Fe} 2+\mathrm{SO} 4 \circ 4 \mathrm{H} 2 \mathrm{O}$ \\
& Szomolnokite & $\mathrm{Fe} 2+\mathrm{SO} 4 \circ \mathrm{H} 2 \mathrm{O}$ \\
& Romerite & $\mathrm{Fe} 2+\mathrm{Fe} 23+(\mathrm{SO} 4) 4 \circ 14 \mathrm{H} 2 \mathrm{O}$ \\
& Copiapite & $\mathrm{Fe} 2+\mathrm{Fe} 43+(\mathrm{SO} 4) 6(\mathrm{OH}) 2 \circ 2 \mathrm{H} 2 \mathrm{O}$ \\
& Jarosite & $\mathrm{KFe} 33+(\mathrm{SO} 4) 2(\mathrm{OH}) 6$ \\
& Plumbojarosite & $(\mathrm{Pb}, \mathrm{K}) \mathrm{Fe}_{3}{ }^{3+}+\left(\mathrm{SO} \mathrm{O}_{4}\right)_{2}(\mathrm{OH})_{6}$ \\
\hline
\end{tabular}

\subsection{External conditions at landfills}

\subsubsection{Carbonization}

Carbonization or up-take of carbon dioxide $\left(\mathrm{CO}_{2}\right)$ from the air or flue gases is very important for waste containing alkaline hydroxide. $\mathrm{CO}_{2}$ uptake leads to the formation of carbonate compounds from hydroxides. As a consequence of carbonation, the $\mathrm{pH}$ of the waste will decrease significantly. In the storage of wastes containing alkaline calcium, a decrease of $\mathrm{pH}$ value can be detected within a few months. Therefore some waste materials, like bottom ash, are usually aged for 6 months in order to allow the stabilization of reactions (and also technical properties).

Both Swedish (Bendz et al. 2006) and Danish scientists (Hjelmar 2007) have reported on a decrease in $\mathrm{pH}$ in leachate of bottom ashes in field studies owing to the carbonation phenomena (see also Chapter 4). Figure 4 from the Danish study (Hjelmar 2007) illustrates the difference between the $\mathrm{pH}$ measured in a column leaching test on MSWI bottom ash (the same MSWI bottom ash as the one for which the ANC is measured in Figure 11) and on leachate from a large test field in which the bottom ash has been used as a sub-base. In the laboratory column leaching test (Lab-søjle) which was performed on crushed bottom ash over a period of three to four weeks, there has not been time for carbonation to lower the $\mathrm{pH}$. In the field test, however, where the data shown represent a period of three to four years, preferential flow and carbonation of the surfaces have taken place and lowered the $\mathrm{pH}$. Even though the ANC for BA is considerable, it is only necessary for carbonation to occur on the surface of the particles that are exposed to the percolating rainwater/leachate for the $\mathrm{pH}$ to drop two to three units. 


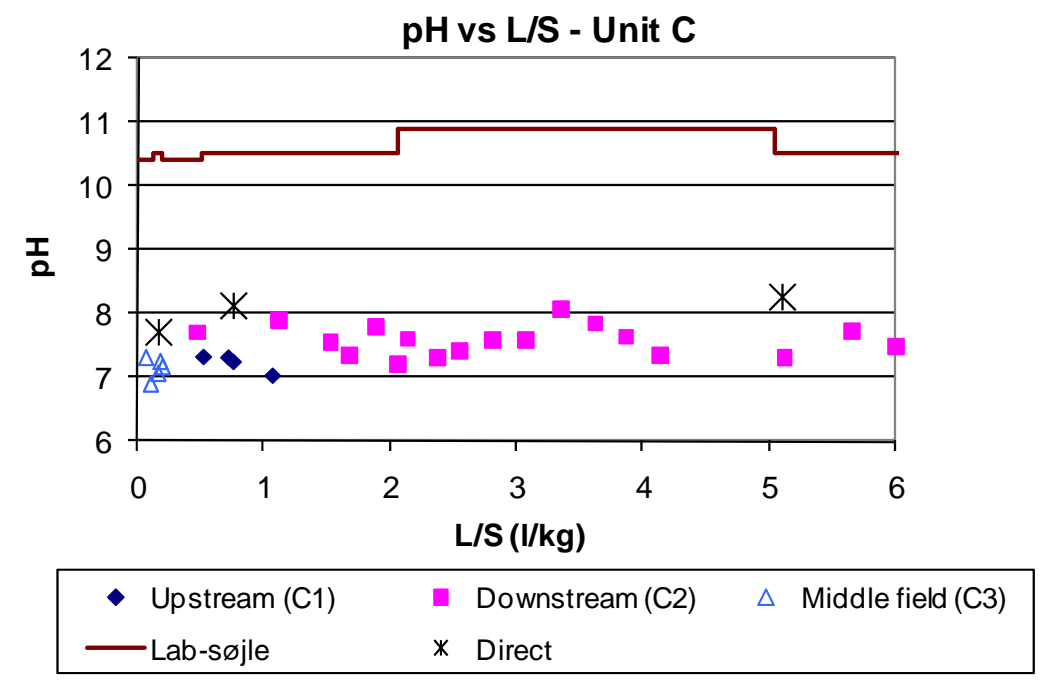

Figure 4. Examples of pH measured in leachate of bottom ash in a field study and in the laboratory test (Hjelmar 2007)

Carbonation of alkaline wastes involves the dissolution of mineral phases and precipitation of new phases. As the carbonates have different solubility, the characteristics of the residue change owing to carbonation. It should be noted that the total ANC of the waste does not change owing to carbonation (Astrup 2004).

The influences of minerals in untreated and carbonated APC residue are illustrated in Fig. 5. The untreated wasted showed a strong acidbuffering capacity at around $\mathrm{pH} 12$ owing to the content of calcium hydroxide species. For the carbonated ash, the acid addition (corresponding to $1 \mathrm{~mol} \mathrm{H}^{+} / \mathrm{kg}$ ) caused a steep drop in $\mathrm{pH}$ to approximately 5.5 units, where a large plateau, typical of the carbonate/bicarbonate buffer, was observed. (The equivalence $\mathrm{pH}$ point of calcium carbonate is around 8.3 and calcium bicarbonate around $\mathrm{pH}$ 5.5).

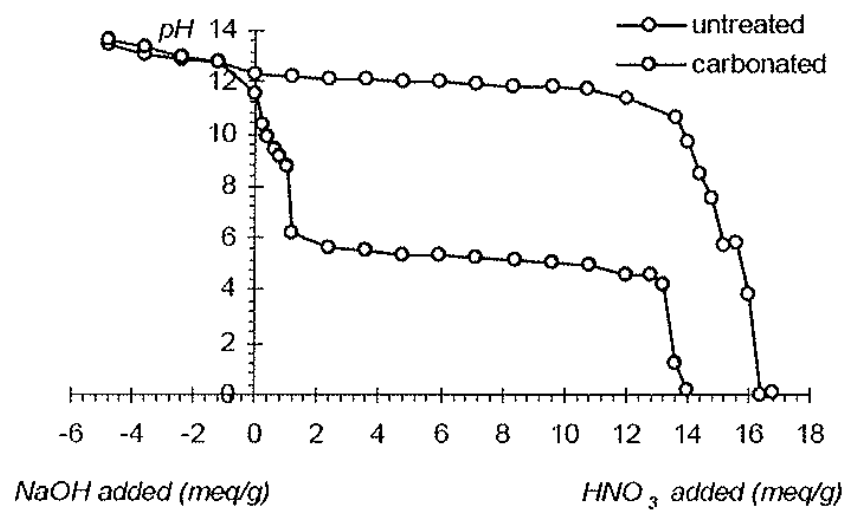

Figure 5. Acid neutralization behaviour of untreated (upper curve) and carbonated APC ash (lower curve). Meq/g = mol/kg (Baciocchi et al. 2008) 
The carbonation process has been extensively studied in the characterization studies of cement-stabilized waste materials (Stegemann 2002). Moreover, several studies on the uptake of carbon dioxide to alkaline materials (e.g. concrete) for reduction of greenhouse gas emissions have been conducted using accelerated carbonation processes (optimal condition with pressure, moisture, temperature). The degree of carbonation in the accelerated processes is significantly higher than in the normal weathering reactions. The reaction time can be shortened owing to optimized humidity, pressure and temperature conditions. Subsequently, the ANC values of untreated ashes and the end $\mathrm{pH}$ values in the accelerated carbonization processes do not reflect the landfill situation.

\subsubsection{Other disposed wastes}

Particularly in cases where different types of wastes (e.g. of different origins) are landfilled in the same landfill area, the influence of leachate from other disposed waste material needs to be taken into account when evaluating waste acceptance at landfills. The focus is on significant waste streams generating leachate with low or high $\mathrm{pH}$. Also materials used in the top cover constructions (e.g. daily cover) may influence the $\mathrm{pH}$ conditions.

Examples of waste materials with low and high $\mathrm{pH}$ values are collated in Table 6. 
Table 6. Examples of waste generating leachate with high $(\mathrm{pH}>9)$ or low $\mathrm{pH}(\mathrm{pH}<5)$.

\begin{tabular}{|c|c|c|c|}
\hline Waste type & $\begin{array}{l}\text { EWC codes } \\
\text { (examples) }\end{array}$ & $\begin{array}{l}\text { Typical } \mathrm{pH} \\
\text { range }\end{array}$ & Remarks \\
\hline $\begin{array}{l}\text { Reclamed concrete (demo- } \\
\text { lition waste) }\end{array}$ & $\begin{array}{l}101314, \\
170101 \\
191212\end{array}$ & $\begin{array}{l}\mathrm{pH}>12 \\
\text { (fresh } \\
\text { waste) }\end{array}$ & fresh concrete surface \\
\hline $\begin{array}{l}\text { Fly ash from wood and } \\
\text { peat combustion }\end{array}$ & $\begin{array}{l}100102 \\
100103 \\
100117\end{array}$ & $\mathrm{pH}>12$ & $\begin{array}{l}\text { wood ash typically contains potas- } \\
\text { sium hydroxide }\end{array}$ \\
\hline APC residues & $\begin{array}{l}190107^{*} \\
190113^{*} \\
190114\end{array}$ & $\mathrm{pH}>12$ & $\begin{array}{l}\text { access of unreacted lime added in } \\
\text { the flue gas treatment system }\end{array}$ \\
\hline Steel slag & $\begin{array}{l}100201 \\
100202\end{array}$ & $\mathrm{pH}>12$ & \\
\hline Bottom ash from MSWI & $\begin{array}{l}190111^{*} \\
190112\end{array}$ & $\mathrm{pH}>10$ & \\
\hline $\begin{array}{l}\text { Dust (foundry, metallurgi- } \\
\text { cal) }\end{array}$ & $\begin{array}{l}101009^{*} \\
101010\end{array}$ & $\mathrm{pH}>10$ & \\
\hline Municipal waste & $\begin{array}{l}200301 \\
200399\end{array}$ & $\mathrm{pH}<7$ & $\begin{array}{l}\mathrm{pH} \text { levels depend on the acidic } \\
\text { phase }\end{array}$ \\
\hline Foundry sand (furan sand) & $\begin{array}{l}101007 \\
101008^{*}\end{array}$ & $\mathrm{pH} 3-5$ & $\begin{array}{l}\text { content of organic acids in binding } \\
\text { agents }\end{array}$ \\
\hline $\begin{array}{l}\text { Paint, sealant, varnish } \\
\text { waste }\end{array}$ & $\begin{array}{l}080112 \\
080410\end{array}$ & $\mathrm{pH}<3$ & $\begin{array}{l}\text { content of organic compounds (e.g. } \\
\text { acids in hardener) }\end{array}$ \\
\hline Jarosite & $110202^{*}$ & $\mathrm{pH}<3$ & \\
\hline $\begin{array}{l}\text { Acid generating tailings } \\
\text { from processing of sulphide } \\
\text { ore (e.g. weathered oxi- } \\
\text { dized sulphidic tailings) }\end{array}$ & $\begin{array}{l}010304^{*} \\
010305^{*} \\
010306\end{array}$ & $\mathrm{pH}<2$ & $\begin{array}{l}\text { the } \mathrm{pH} \text { dependent on neutralization } \\
\text { minerals, oxidation rate }\end{array}$ \\
\hline
\end{tabular}

A special category of waste is sulphide-containing waste such as mining wastes (waste rock) and residues from ore processing (tailings) for which the potential for acid drainage generation may be the key concern in the management of these types of waste. Acid rock drainage (ARD) may be produced where sulphide minerals are exposed to the atmosphere (oxygen and water) and there are insufficient readily-available buffering minerals present. The reactions are also significantly enhanced by the presence of bacteria (Thiobacilus ferrooxidanse).

These reactions can occur in waste-rock deposits, marginal ore deposits, temporary storage piles for the ore, tailings deposits, pit walls, underground workings, or in heap leach piles. When excavated and brought to the surface, the exposure to atmospheric oxygen starts a series of biogeochemical processes that can lead to production of acid mine drainage. When the sulphides oxidize, they produce sulphate, hydrogen ions and dissolved metals. The release of ARD to surface- and groundwater deteriorates the water quality and may cause a number of impacts, such as depletion of alkalinity, acidification, release of metals, effects on habitats, elimination of sensitive species and unstable ecosystems. 


\section{.2.4.2 Acid rains}

Natural unpolluted rainfall is slightly acidic because of the presence of dissolved carbonic acid. The $\mathrm{pH}$ of "normal" rain has traditionally been given a value of 5.6 (pure water in equilibrium with atmospheric carbon dioxide). However, scientists now believe that the $\mathrm{pH}$ of rain may vary from 5.6 to a level of 4.5 with the average value of 5.0. Human activities continuously produce more of these acidifying compounds, resulting in the formation of sulphuric and nitric acid in rainwater. Because of these strong acids, the $\mathrm{pH}$ of rain becomes less than 5 . In the Nordic countries, where emissions of sulphur and nitrogen oxides are strictly controlled, a low $\mathrm{pH}$ value in the rainwater is probably due to the long-range transboundary air pollution.

Acid rain or acid snow is a direct result of the method with which the atmosphere cleans itself. The tiny droplets of water that make up clouds continuously capture suspended solid particles and gases in the atmosphere. The gases of sulphur oxides and nitrogen oxides are chemically converted into sulphuric and nitric acids:

$\mathrm{SO}_{2}+\mathrm{HOH} \rightarrow \mathrm{H}_{2} \mathrm{SO}_{3}$

$2 \mathrm{NO}_{2}+\mathrm{HOH} \rightarrow \mathrm{HNO}_{2}+\mathrm{HNO}_{3}$

The influence of rainwater on alkaline waste material is usually very limited and often not significant compared to other sources. Examples: one litre of rainwater with a pH between 4 and 5 contains about $5 \times 10^{-5} \mathrm{~g}$ $\mathrm{H}^{+} / \mathrm{l}$ or $0.05 \mathrm{mmol} \mathrm{H}^{+} / \mathrm{l}$. For example, at an extreme L/S ratio of 1000 , this means a neutralization demand of $0.5 \mathrm{~mol} / \mathrm{kg}$. (Astrup 2004)

The main concern related to acid rains is connected with the damage to buildings and constructions and not especially waste materials. Acid rain typically causes damage, e.g. to building materials and historical monuments made of limestone, marble or granite. The sulphur acid in the rain chemically reacts with the calcium compounds in the stones (limestone, sandstone, marble and granite) to create gypsum, which then leaches off. Earlier, also the corrosion of metals was of major concern. 


\section{Determination of ANC}

In this section, general aspects of importance for the evaluation of the ANC are discussed. Material-related properties and the related test methods are discussed further in Section 4. All the described methods give information on the total neutralization capacity, but no information is provided on the time-dependence or the neutralization rate in field conditions. For conversion of the results to a time scale other evaluation tools (modelling, field data) are needed.

\subsection{Experimental methods}

The acid neutralizing capacity is often defined as a measure of the amount of base present that can accept hydrogen ions from a strong acid. Since the extent of these acid base reactions is dependent on $\mathrm{pH}$, the ANC is a function of pH. However, a single value of ANC is often reported by choosing a specific $\mathrm{pH}$ for determination. Very often a curve of the ANC characteristics for a specific waste is presented.

In the laboratory, ANC is usually determined by digesting a sample in a solution containing acid. Acid consumed in fixed testing conditions represents the ANC of a sample. Table 7 shows the basic principles of tests developed to measure the ANC of waste materials. 
Table 7. European test methods developed for determination of the neutralization potential of waste.

\begin{tabular}{|c|c|c|c|}
\hline Test & $\begin{array}{l}\text { pH-dependence test } \\
\text { CEN/TS14997 }\end{array}$ & $\begin{array}{l}\text { pH-dependence test } \\
\text { CEN/TS } 14429\end{array}$ & Static test prEN 15875 \\
\hline Test level & Basic characterization & Basic characterization & $\begin{array}{l}\text { Screening / compliance } \\
\text { testing }\end{array}$ \\
\hline Scope & \multicolumn{2}{|c|}{$\begin{array}{l}\text { Primarily influence of } \mathrm{pH} \text { on the leachability of inor- } \\
\text { ganic constituents from waste materials }\end{array}$} & $\begin{array}{l}\text { The potential of sul- } \\
\text { phide-bearing materials } \\
\text { to form acidic drainage }\end{array}$ \\
\hline $\begin{array}{l}\text { Developed for } \\
\text { (materials) }\end{array}$ & All waste materials & All waste materials & $\begin{array}{l}\text { Sulphidic extractive } \\
\text { waste }\end{array}$ \\
\hline Principle & $\begin{array}{l}\text { Sample is mixed with } \\
\text { distilled water and } \mathrm{pH} \\
\text { level of the solution is } \\
\text { kept at a predetermined } \\
\mathrm{pH} \text { value by using an } \\
\text { automated pH titrator }\end{array}$ & $\begin{array}{l}\text { Sample is mixed with } \\
\text { leachant containing pre- } \\
\text { selected amounts of acid } \\
\text { or base in order to reach } \\
\text { stationary } \mathrm{pH} \text { values at } \\
\text { the end of the extraction } \\
\text { period }\end{array}$ & $\begin{array}{l}\text { Digestion of sample with } \\
\text { acid. Acid is back- } \\
\text { titrated to } 8.3\end{array}$ \\
\hline $\begin{array}{l}\text { Sample } \\
\text { amount }\end{array}$ & 15,30 or $60 \mathrm{~g}$ & 15,30 or $60 \mathrm{~g}$ & $2 \mathrm{~g}$ \\
\hline $\begin{array}{l}\text { Sample grain } \\
\text { size }\end{array}$ & $<1 \mathrm{~mm}$ & $<1 \mathrm{~mm}$ & $<0.125 \mathrm{~mm}$ \\
\hline Target $\mathrm{pH}$ & $\begin{array}{l}\text { Each } \mathrm{pH} \text { value tested } \\
\text { separately. Typically } \mathrm{pH} \\
\text { range } 3-12 \text { covered (to } \\
\text { be selected based on } \\
\text { material and disposal } \\
\text { conditions) }\end{array}$ & $\begin{array}{l}\text { Each } \mathrm{pH} \text { value tested } \\
\text { separately. Typically } \mathrm{pH} \\
\text { range } 3-12 \text { covered (to } \\
\text { be selected based on } \\
\text { material and disposal } \\
\text { conditions) }\end{array}$ & $\begin{array}{l}\text { Digestion around } \mathrm{pH} 2 \text {, } \\
\text { back titration of excess } \\
\text { acid to } \mathrm{pH} 8.3 \\
\text { (digestion } \mathrm{pH} \text { only } \\
\text { roughly controlled) }\end{array}$ \\
\hline L/S & Target 10 & Target 10 & 45 plus acid added \\
\hline Test duration & $48 \mathrm{~h}$ & $48 \mathrm{~h}$ & $24 \mathrm{~h}$ \\
\hline Mixing & Stirring (horizontal) & $\begin{array}{l}\text { End-over-end tumbler or } \\
\text { roller table }\end{array}$ & Stirring (horizontal) \\
\hline $\begin{array}{l}\text { Requirement } \\
\text { on achieve- } \\
\text { ment of equi- } \\
\text { librium condi- } \\
\text { tion in test }\end{array}$ & yes & yes & no \\
\hline Test limitations & $\begin{array}{l}\text { Time-dependent leach- } \\
\text { ing of substances } \\
\text { (slowly leachable) not } \\
\text { addressed } \\
\text { Matrix interference }\end{array}$ & $\begin{array}{l}\text { Time dependent leach- } \\
\text { ing of substances } \\
\text { (slowly leachable) not } \\
\text { addressed } \\
\text { Matrix interference }\end{array}$ & $\begin{array}{l}\text { Only fast reactive com- } \\
\text { pounds included } \\
\text { Relevance of grain size } \\
\text { requirement for waste } \\
\text { rock }\end{array}$ \\
\hline \multirow[t]{2}{*}{$\begin{array}{l}\text { Expression of } \\
\text { results }\end{array}$} & $\begin{array}{l}\text { Acid/base added for } \\
\text { each target } \mathrm{pH}\end{array}$ & $\begin{array}{l}\text { Acid/base added for } \\
\text { each target } \mathrm{pH}\end{array}$ & \multirow{2}{*}{$\begin{array}{l}\text { Calculation of NPR ratio } \\
\text { (the ratio between NP } \\
\text { and AP) }\end{array}$} \\
\hline & $\begin{array}{l}\text { Concentrations of } \\
\text { analyzed substance in } \\
\text { test eluates for each } \\
\text { target } \mathrm{pH}\end{array}$ & $\begin{array}{l}\text { Concentrations of } \\
\text { analyzed substance in } \\
\text { test eluates for each } \\
\text { target } \mathrm{pH}\end{array}$ & \\
\hline \multirow[t]{2}{*}{$\begin{array}{l}\text { Criteria for test } \\
\text { interpretation }\end{array}$} & No & No & $\begin{array}{l}\text { EU criteria for inert mine } \\
\text { waste classification } \\
\text { (Commission Decision } \\
\text { 2009) }\end{array}$ \\
\hline & & & $\begin{array}{l}\text { Indicative NPR values for } \\
\text { identification of risk of for- } \\
\text { mation of acid drainage }\end{array}$ \\
\hline
\end{tabular}




\subsubsection{CEN/TS 14997 with continuous $\mathrm{pH}$ control}

In CEN/TS 14997 test sample (15, 30 or $60 \mathrm{~g}$ ) is mixed with distilled water for 48 hours at an L/S ratio of about 10 . The $\mathrm{pH}$ level of the mixture is kept at the predetermined $\mathrm{pH}$ value by using an automated $\mathrm{pH}$ titrator. An equilibrium is established as a result of continuous adjustment of $\mathrm{pH}$. Size reduction $(<1 \mathrm{~mm})$ of the sample is performed to accelerate reaching of equilibrium. The acid or base consumption recorded by a titrator shows the ANC or BNC at a given $\mathrm{pH}$ value.

\subsubsection{CEN/TS 14429 with initial acid/base addition}

Separate test portions are leached at a fixed L/S ratio with leachants containing pre-selected amounts of acid or base in order to reach stationary $\mathrm{pH}$ values at the end of the extraction period. Each leachant is added in three steps in the beginning of the test. At least 8 final $\mathrm{pH}$ values are required, covering at the minimum the range $\mathrm{pH} 4$ to $\mathrm{pH} 12$ (both included, i.e. the lowest value $\leq 4$ and the highest value $\geq 12$ ). The amounts of acid or base needed to cover the $\mathrm{pH}$ range can be derived from the results of a preliminary titration, from available experimental data on the material to be tested or from an arbitrary division of the predetermined maximum consumption of acid and base. The tests are carried out at a fixed contact time at the end of which equilibrium condition can be assumed to be reached for most constituents in most waste materials to be characterized.

\subsubsection{Static test prEN 15875}

In the Static test prEN 15875 test 2 grams of finely ground sample is digested for 24 hours in $90 \mathrm{ml}$ of $\mathrm{HCl}$ solution. The test aims at final digestion $\mathrm{pH}$ of 2.0-2.5 and the amount of $1 \mathrm{M} \mathrm{HCl}$ added to the solution in the early stages of the test is determined on the basis of the carbonate content. After digestion the solution is back titrated to $\mathrm{pH} 8.3$ to measure the amount of acid left in the solution. The acid consumption in the test is converted to the neutralization potential (ANC) of a sample.

\subsubsection{Comparison of European methods for ANC testing}

An example of testing of mining waste (tailings) is shown here since it allows a comparison of ANC results gained with all of the different test methods described in Section 3.1. 


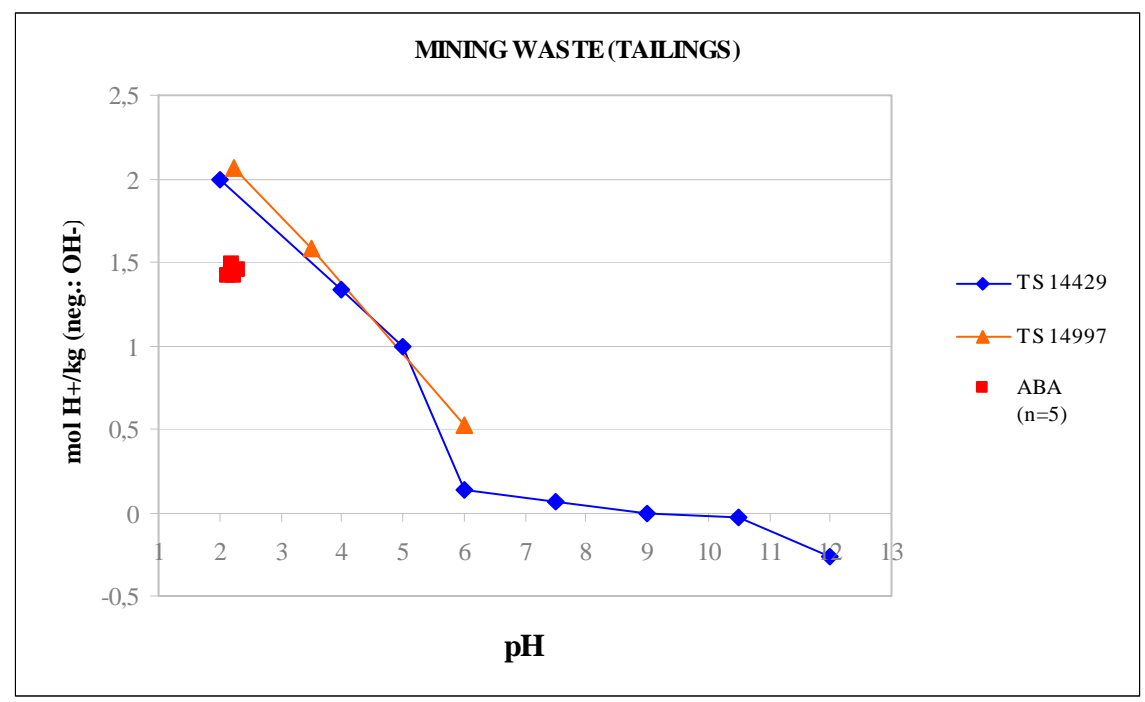

Figure 6. Example of ANC for mining waste with different tests. ABA test corresponds to the static test

The results from CEN/TS 14429 and CEN/TS 14997 are almost similar. The static test seems to give lower values for ANC. This can probably be explained by the nature of the tests. In the static test prEN 15875 only three time-points to add acid to the mixture exist. Between the acid additions the $\mathrm{pH}$ of the mixture climbs thus preventing the buffering of some minerals that are only active at lower $\mathrm{pH}$ levels.

\subsection{Other supplementary approaches}

The release of contaminants from a solid material is often controlled by (geo)chemical mechanisms, such as solubility of minerals/salts, sorption to reactive mineral and organic surfaces and complexation to (in)organic ligands. These fundamental processes dictating the leaching can be modelled using appropriate leaching data and speciation models. For the production of data to be used in hydrogeological modelling, a widening of the $\mathrm{pH}$ range will be useful (e.g. $\mathrm{pH}=1$ to 13 ).

The ANC results from $\mathrm{pH}$-dependence testing (and also static test) often correlate with the dissolution of calcium-containing minerals or materials. Secondary minerals, which may precipitate and later re-dissolve, are important to the neutralizing processes (Yan et al. 1998). Ashes and slag also consist of a considerable amount of amorphous phases that also contribute to ANC, which are difficult to evaluate through short-time batch testing. The understanding of secondary minerals and amorphous phases can be evaluated through geochemical modelling.

The effective NP of mine waste can also be calculated based on the mineralogical composition of a sample and relative mineral reactivity of minerals (see Table 3). Different minerals can neutralize acid drainage at 
different rates and in different $\mathrm{pH}$ ranges. The test conditions of widely used laboratory procedures to determine NP do not distinguish between such differences and overestimation of NP can often result. The calculation method is based on the determination of the major rock-forming elements of a sample, usually referred to as whole rock analysis, in combination with the analysis of inorganic carbon (carbonate), as inputs to the calculations. A major advantage of this approach is that whole rock analyses are often already available, having been determined as part of the exploration and ore-mapping process. The procedure is considered to be a cost-effective means of providing confident routine ARD prediction when used in combination with other tests and analyses. (Lawrence et al. 1997, Packtunc 1999).

\subsection{Practical aspects of testing (observations, challenges)}

The European static test prEN 15875 is especially developed for extractive waste containing sulphides. The static test is a simplified method of the $\mathrm{pH}$-dependence tests and therefore generally not useful for waste material characterization. The method is still under development and experience from a huge material record is therefore lacking. The method is, however, very similar to previous versions of the static test used in the mining sector. The test conditions are more specified than in the earlier versions. In practice, it is believed that, owing to the boundary conditions in test performance (i.e. the maximum acid amount to be added at the end of the test), it is likely the test must be re-done in some cases. It is important to understand that the static test prEN 15875 is a very rough and simple method only giving indicative information of neutralization potential.

More information on the $\mathrm{pH}$ behaviour can be gained from $\mathrm{pH}$ dependence CEN/TS 14997 with continuous $\mathrm{pH}$ control (pH static test) and the pH-dependence test CEN/TS 14429 with initial acid/base addition. Based on practical experience, the $\mathrm{pH}$ static test is easier to perform than the test with initial acid/base addition but requires special laboratory equipment (automized titrator). The $\mathrm{pH}$ static test is easier to control and its parameters can be changed during the experiment. Since the $\mathrm{pH}$ is controlled continuously and at a certain set point, one can be sure that the test material is leached at the desired $\mathrm{pH}$ value. (Laine-Ylijoki et al 2005, Lehmann et al 2000)

The test with initial acid/base addition is more labour-consuming. In the first step, the preliminary titration experiment has to be carried out as accurately as possible in order to determine the amount of acid or base to be added. In the second step, three equally large portions of leachant have to be prepared, which are added in the beginning of the experiment, after 30 minutes and after 2 hours, respectively. This can be a source of error and once the leachant has been added, one has no influence on the test. If 
the expected $\mathrm{pH}$ value is not reached after 30 minutes or 2 hours, the test can be started over again. Even if the expected $\mathrm{pH}$ value is reached after 2 hours, this is no guarantee that the set-point $\mathrm{pH}$ will be reached after 48 hours - at the end of the experiment.

For the majority of wastes, both test CEN/TS 14229 with initial acid/base addition and $\mathrm{pH}$ static test CEN/TS 14997 can be carried out without any major problems. For certain waste characteristics, testing according to testing requirements is not feasible. Examples of such characteristics are as follows:

- metallic iron waste itself produces acid after an initial acid addition, which means that equilibrium conditions cannot be reached in the test;

- test material with low density cannot be tested with horizontal stirring used in CEN/TS 14997 (pH static with continuous pH control) because the test material is not well mixed in with the leachant;

- non-crushable materials (e.g. plate-like materials, mineral wool) cannot be tested according to the grain size requirements;

- especially soil testing at neutral pH with CEN/TS 14429 (test with initial acid/base addition) is practically difficult to control owing to buffering compounds in the soil test (this might cause a practical problem for DOC testing at a specific $\mathrm{pH}$ neutral range). 


\section{Rating of ANC properties}

In this section, ANC results for typical waste streams are presented and discussed. The aim is to analyze the information derived from ANC test on waste behaviour and to give background for the general conclusions in Section 5.

\subsection{Base for evaluation}

In the ANC testing of waste, especially the ability of a material to neutralize acid or base is typically evaluated at a selected $\mathrm{pH}$ value. Both the neutralization potential and acid potential are of importance in the evaluation of ANC properties. Generally, in ANC testing more focus is given to the neutralization potential than to the acid potential of the waste. A special case is always waste subjected to carbonation (here $\mathrm{pH}$ change to $\mathrm{pH}$ around 8 will occur independent of the neutralization potential values).

The real effects on-site including the external effects need to be assessed by testing weathered samples from the field or by monitoring of the actual $\mathrm{pH}$ in the landfill leachate. The evaluation of a given neutralization potential depends on the longer term conditions under which the waste will be placed and on whether the potential acidification is inherent in the waste (i.e. whether it has an acid-producing capacity) or whether the $\mathrm{pH}$ change will occur only through external influences.

The critical value for the neutralization potential depends thus on the case in question. No clear indications of critical values for the neutralization potential are presented in the literature. Moreover, the neutralization potential values are also pH-dependent. In Section 2.3.1, examples of neutralization potential values for some minerals are presented. The values for the slow weathering minerals (with low practical meaning in neutralization) lie around $0.2 \mathrm{~mol} \mathrm{H}^{+} / \mathrm{kg}$ at $\mathrm{pH}$ 4-5. Furthermore, in Section 2.3.3, it is shown that the sulphide content of 0.1 weight \% (which is also the limit for inert waste requiring no further ARD testing) creates an acid potential (and thus also a demand for the neutralization potential) of $0.6 \mathrm{~mol} \mathrm{H}^{+} / \mathrm{kg}$.

Based on the observations above, an indication of a low and critical $\mathrm{NP}$ value is here chosen as $0.2 \mathrm{~mol} \mathrm{H}^{+} / \mathrm{kg}$. Actually, also a value of 0.6

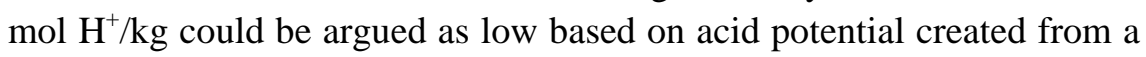
sulphide content of $0.1 \%$.

Calcite $\left(\mathrm{CaCO}_{3}\right)$, having a neutralization potential of $20 \mathrm{~mol} \mathrm{H}^{+} / \mathrm{kg}$, is a fast reactive mineral and usually indicates an upper limit for the neutralization potential (note: higher values can appear). From a practical 
point of view in testing, a value of 3-4 mol/ $/ \mathrm{kg}$ at $\mathrm{pH} 4-5$ can be seen as an example of high neutralization capacity

\subsection{Examples of ANC results}

The following sections show examples of results from testing the acid (and base) neutralization capacity of some waste materials produced in significant quantities.

The $\mathrm{Y}$-axis in the figures shows the amount of acid needed in $\mathrm{pH}-$ dependent test (CEN/TS 14997 or CEN/TS 14429) to reach and maintain the pre-set $\mathrm{pH}$ value in the test. The negative $\mathrm{Y}$-axis values show the amount of base needed at a given $\mathrm{pH}$. The point where a curve crosses the $\mathrm{X}$-axis roughly corresponds to the initial $\mathrm{pH}$ of a material. A steep slope of the curve indicates a high capacity of the material to resist $\mathrm{pH}$ changes at the prevailing $\mathrm{pH}$ domain.

\subsubsection{Waste with high initial $\mathrm{pH}$}

Fly ashes generally have a high initial $\mathrm{pH}$ and relatively good buffering capacity against acid additions. Changes in ANC depending on fuel are significant as shown in Figure 7. For example, adding $25 \%$ of wood fly ash to peat fly ash more than doubles the ANC of the ash. The ANC levels correlate well with the estimated calcite content in the ashes.

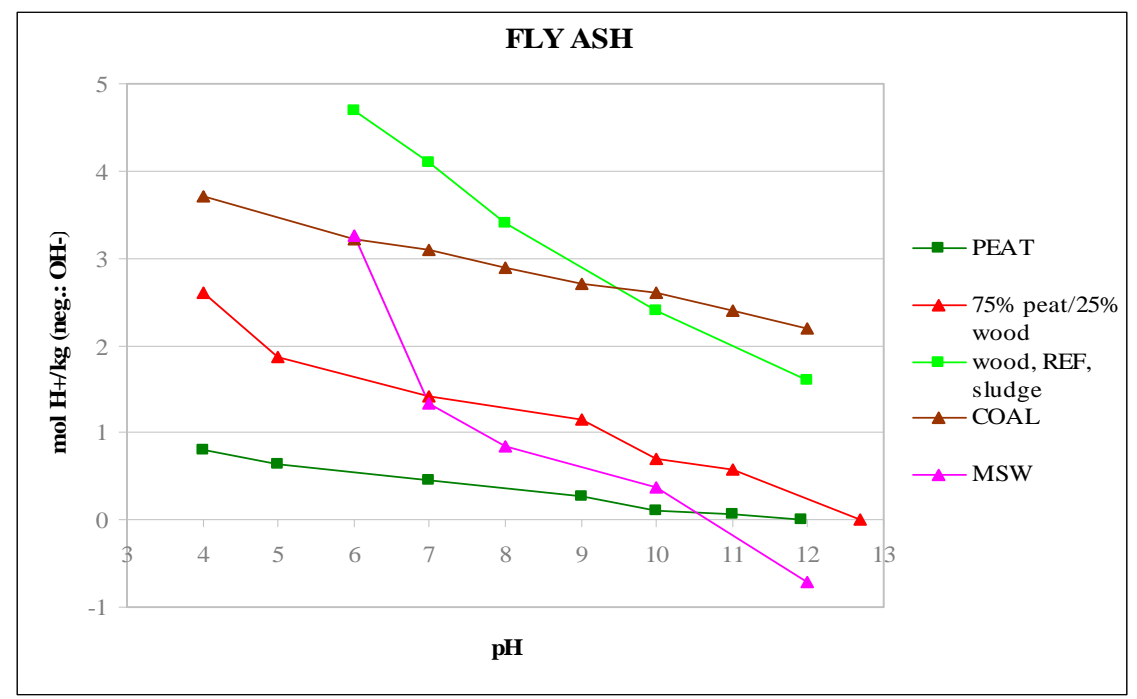

Figure 7. Examples of acid and base neutralization capacity as a function of $\mathrm{pH}$ for fly ashes resulting from incineration of different materials. MSW fly ash includes APC residues. Test methods used are CEN/TS 14997 and CEN/TS 14429.

Bottom ashes from municipal solid waste incineration have varying capacities to resist acid additions owing to their calcite content. However, 
the curves for different bottom ashes as a function of $\mathrm{pH}$ have quite a similar pattern. Almost all of the bottom ashes in Figure 8 have an ANC of more than $1 \mathrm{~mol} \mathrm{H}^{+} / \mathrm{kg}$ at $\mathrm{pH} 4$. Also the slope of the ANC curve is steepest for most of the bottom ashes between $\mathrm{pH} 4$ and 6 .

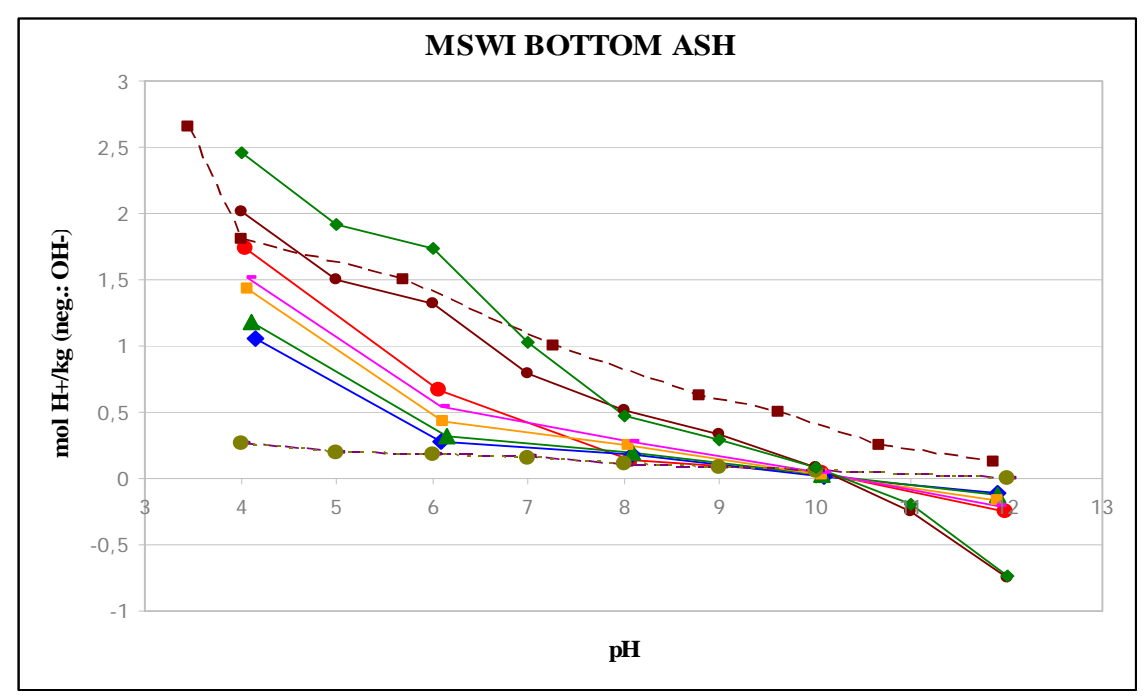

Figure 8. Acid and base neutralization capacities as a function of $\mathrm{pH}$ for bottom ashes from municipal solid waste incineration (MSWI).

Many metallurgical slags also have a high initial $\mathrm{pH}$ and relatively good ANC (Figure 9). Exceptions do exist, such as slag from a nickel smelter (own $\mathrm{pH}$ 8-9) that has a very weak ability to resist $\mathrm{pH}$ changes in both directions. This might be owing to the glass formation of the nickel slag.

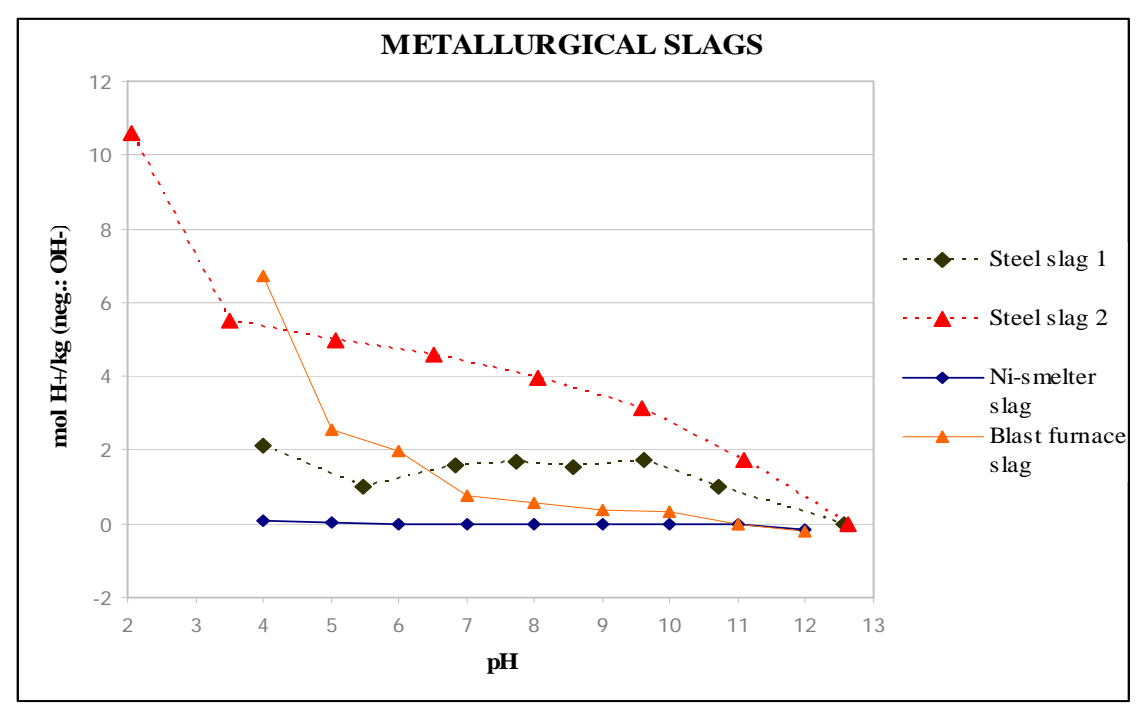

Figure 9. Examples of acid and base neutralization capacity as a function of $\mathrm{pH}$ for some typical metallurgical slags. 


\subsubsection{Neutral waste}

Figure 10 shows an example of ANC/BNC behaviour of nearly neutral wastes. Typical examples of neutral wastes are soil and some organic waste (compost).

It should be noted that the buffer capacity of soil may vary significantly depending on the organic and mineral content. Soil sample 2 in Figure 10 represents a highly "fertilized" soil giving a high neutralization potential at $\mathrm{pH} 4$ (Elert et al 2008). In several case studies with soil, a low

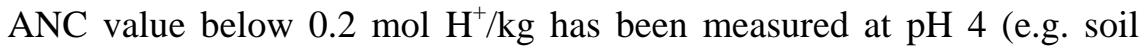
sample 3 in Figure 10).

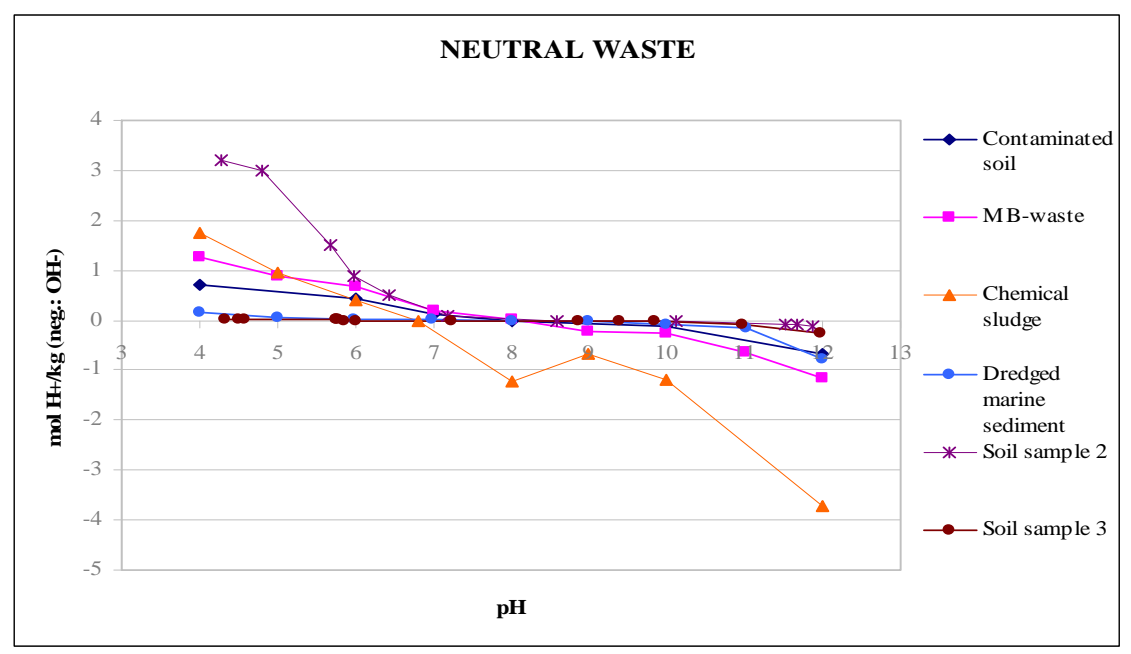

Figure 10. Examples of ANC and BNC as a function of $\mathrm{pH}$ for neutral wastes. MB waste corresponds to mechanically and biologically treated municipal solid waste.

It can be seen from Figure 10 that these types of wastes with nearly neutral initial $\mathrm{pH}$ exhibit the capacity to resist both acid and base additions. The chemical sludge in particular has a high base-neutralization capacity, which might be due to the buffering of organic material.

\subsubsection{Evaluation of ANC behaviour near the waste's own $\mathrm{pH}$}

Another way of expressing the results of an ANC test is illustrated for an MSWI bottom ash (BA) in Figure 11, which shows the amount of acid needed to change the $\mathrm{pH}$ from one value (e.g. the waste material's own or original $\mathrm{pH}$ ) to another $\mathrm{pH}$. This should then be evaluated in the context of the results of a pH-dependence leaching test performed on the same waste material.

In this case, the neutralization capacity has only been determined as ANC, not including BNC (the capacity of the material to neutralize base). Both are prescribed in the CEN tests (CEN/TS 14997 and CEN/TS 14429) but since nearly all processes likely to occur in an MSWI BA monofill will tend to decrease $\mathrm{pH}$, only the ANC data are necessary for a 
simple evaluation of the long-term behaviour of the MSWI BA (if hydrogeochemical speciation modelling is included, however, the entire $\mathrm{pH}$ range should be covered).

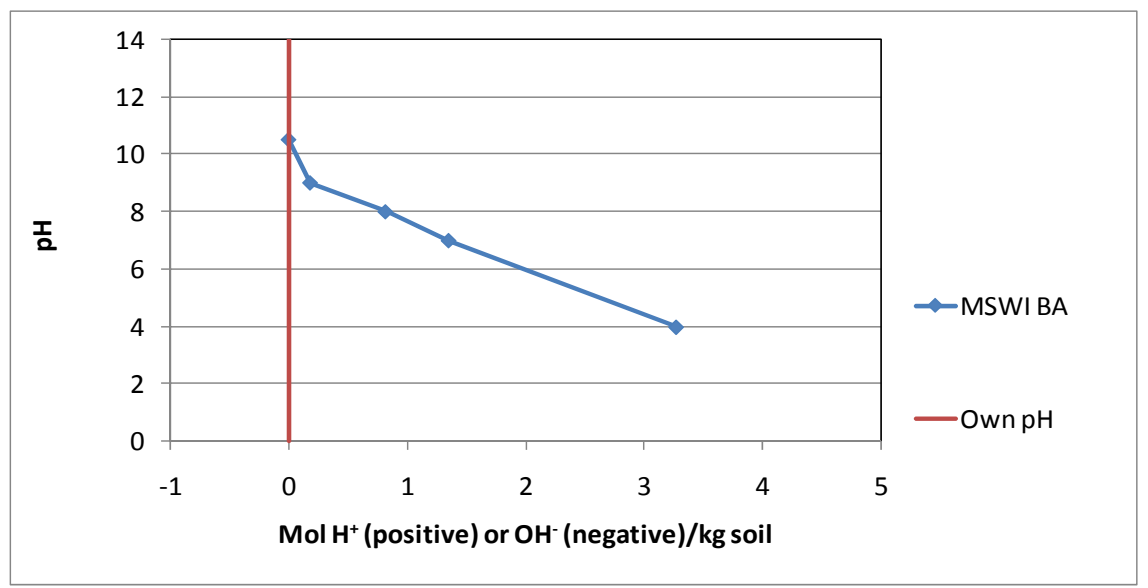

Figure 11. pH change as a function of acid addition for MSWI bottom ash.

Figure 12 shows the dependence of Zn leaching from the same MSWI $\mathrm{BA}$ on $\mathrm{pH}$. From Figure 12 it can be seen that if $\mathrm{pH}$ changes from the bottom ash's original $\mathrm{pH}$ of 10.5 to a $\mathrm{pH}$ of, e.g. 8.0, which could easily happen owing to carbonation, then the leachability of $\mathrm{Zn}$ would increase by almost a factor of 100 . The amount of acid $\left(\right.$ or $\left.\mathrm{CO}_{2}\right)$ needed to effect this change can be estimated from Figure 11 to be around $1 \mathrm{~mol} \mathrm{H}^{+} / \mathrm{kg}$.

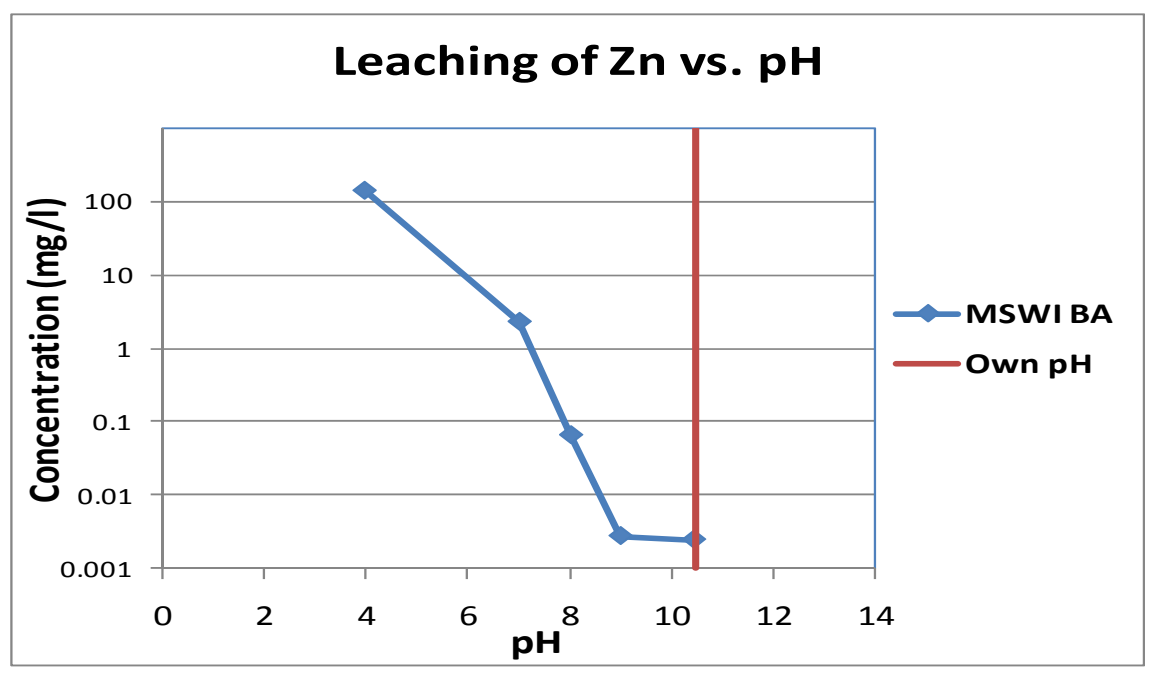

Figure 12. ANC measurement on MSWI bottom ash (BA) and pH-dependence of the leaching of Zn from MSWI bottom ash. 


\subsection{Correlation of results with composition}

The total calcium content can often be indicative of the acid neutralization capacity of a material. However, this cannot be used as a direct measurement of ANC as is evident from Figure 13.

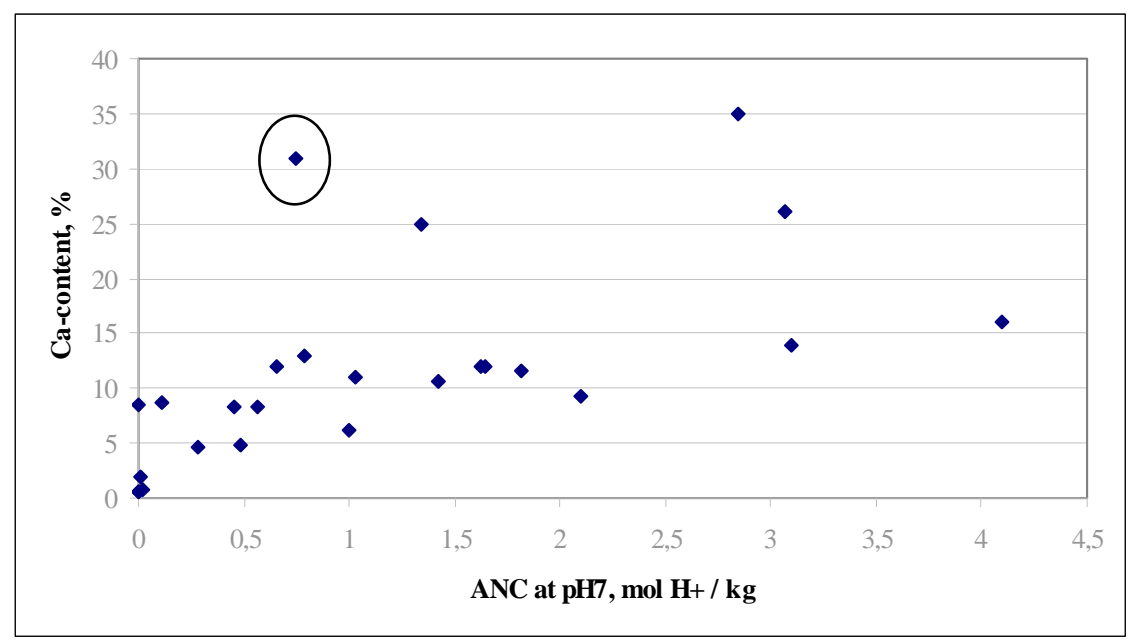

Figure 13. Calcium content versus ANC at $p H 7$ for variety of waste materials with alkaline initial $\mathrm{pH}$.

Generally, the content of calcium correlates with the measured ANC at $\mathrm{pH} 7$ for alkaline waste materials (bottom ashes, fly ashes, slags). Exceptions do exist, which favours the measurement of ANC even in cases where a high Ca content is found. For instance, the circled value in Figure 13 shows an extremely high Ca content of $31 \%$ but only moderate ANC at pH $7\left(0.75 \mathrm{~mol} \mathrm{H}^{+} / \mathrm{kg}\right)$. The material in question is a metallurgical slag in which calcium appears mostly in silicate minerals that do not strongly buffer the $\mathrm{pH}$ of a solution in an ANC test.

For mine waste, it is possible to identify the main neutralizing mineral and a more reliable correlation is shown based on mineralogical data. Several different types of calculation (computer) models have been presented using different factors for specific minerals (Lawrence et al. 1997, Paktunc 1999).

\subsection{Field data}

The accumulated effects of leaching and ageing in a sub-base layer of bottom ash in a 16 year-old paved test road were investigated in a Swedish study (Bendz et al. 2006). The bottom ash that was used in the subbase layer was fresh at the time of the construction of the test road with a $\mathrm{pH}$ of about 11. 
The measured $\mathrm{pH}$ values in the collected bottom ash samples also show horizontal gradients with decreasing values towards the shoulder slopes and a $\mathrm{pH}$ front propagating from the road shoulders towards the centre of the road. This indicates a reaction with atmospheric carbon dioxide. The spatial distribution of leachable trace elements in the sub-base layer was found to reflect the distribution of $\mathrm{pH}$ and the ageing process.

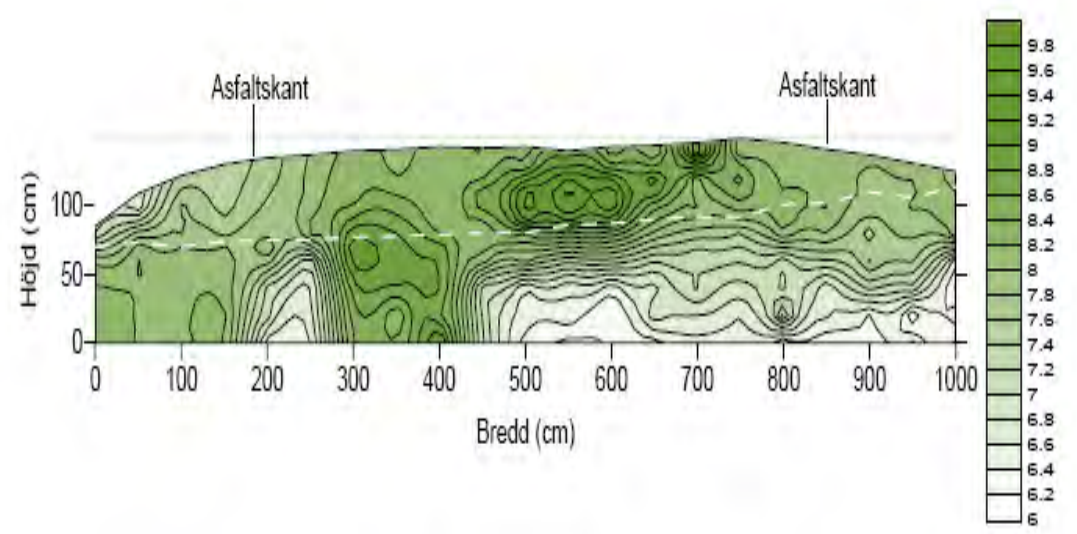

Figure 14. pH fronts in a road sub-base layer of bottom ash (Bendz et al. 2006) 



\section{Conclusions and recommendations}

\subsection{Testing aspects}

Both pH-dependence tests (CEN/TS 14997, CEN/TS 14429) developed for waste characterization are appropriate for testing the ANC properties. The test description requires that at least $8 \mathrm{pH}$ values are tested. The ABA method (static test prEN 15875) is especially developed for extractive waste containing sulphides. The static test is a simplified method of the $\mathrm{pH}$-dependence tests and therefore generally not useful for waste material characterization.

Based on practical experience, the $\mathrm{pH}$ static test with continuous $\mathrm{pH}$ control, CEN/TS 14997, is easier to perform than the test with initial acid/base additions CEN/TS 14429. Since the $\mathrm{pH}$ is controlled continuously and at a certain set point, one can be sure that the desired $\mathrm{pH}$ value is achieved. However, it is important to ensure that a significant volume of acid or base is not added in the final phase of the test. The following general recommendations can be made:

- The starting point for waste materials not previously studied is to cover the whole $\mathrm{pH}$ range ( $\mathrm{pH} 3-12)$. The testing requirement can be narrowed down to a critical $\mathrm{pH}$ range, when it is possible to rely on existing data for similar material.

- In the case of a high buffer capacity, the testing can be narrowed to a critical range (to be decided case by case, e.g. for cement stabilized waste $\mathrm{pH}>8$ is only of concern).

- For the production of data to be used in hydrogeological modelling, a widening of the $\mathrm{pH}$ range will be useful (e.g. $\mathrm{pH}=1$ to 13).

\subsection{Evaluation of ANC for waste acceptance}

The Council Decision 2003/33/EC only sets requirements for ANC data for a few landfill categories, i.e. landfills for hazardous wastes and for hazardous waste to be disposed at non-hazardous landfill and also for nonhazardous waste disposed in the same cell as stable non-reactive hazardous waste. However, the ANC (including analysis of the leachability of critical compounds) is relevant also for other landfill categories, especially when different types of waste streams are disposed at the same landfill or cell of a landfill. Particularly in the case where waste containing organic fractions 
(e.g. paper sludge) is disposed on the same landfill, the information of the buffer capacity of the waste and the leaching behaviour in the critical $\mathrm{pH}$ range is important, because the degradation of organic compounds and the subsequent formation of organic acids may cause aggressive conditions. In monofill landfills the waste behaviour is more predictable and an evaluation of the long-term $\mathrm{pH}$ conditions in the landfill can be carried out based on results from laboratory tests and modelling (e.g. risk related to acid generation of sulphide-containing waste).

ANC behaviour can be evaluated in two ways:

- Evaluation of the overall neutralization capacity of a waste to resist $\mathrm{pH}$ change to a specific target $\mathrm{pH}$ value. Especially for small waste amounts, one or a few target $\mathrm{pH}$ values are typically selected (e.g. ANC evaluation at $\mathrm{pH} 4$ ).

- Evaluation of the change in the leachability of critical substances in a $\mathrm{pH}$ range that can likely occur for a certain waste material under prevailing disposal conditions (e.g. caused by carbonization process). Especially for a significant waste amount the latter type of evaluation is used.

Some general recommendations:

- The ANC together with $\mathrm{pH}$ are important parameters to identify waste with extreme properties that may affect other waste domains in the landfill (co-disposal), stability or the durability of the construction and leachate construction system. For specific co-disposal scenarios and site-specific conditions target values for "safe" disposal can be developed.

- It is not possible to give general recommendations for "safe" ANC values. For the evaluation of the magnitude of a safe ANC value, information on the waste-specific compounds (neutralization minerals, sulphides) and external effects is needed. Indications of a critical "low" neutralization capacity or "ANC value" at $\mathrm{pH} 5$ lies at values around $0.2 \mathrm{~mol} \mathrm{H}^{+} / \mathrm{kg}$. However, as explained in Section 2.3.3, a sulphide content of $0.1 \%$ creates theoretically an acid potential of 0.6 $\mathrm{mol} \mathrm{H}^{+} / \mathrm{kg}$ (which means that for this kind of waste at least an equivalent acid neutralization capacity is required).

- The carbonation process of calcium hydroxide (and also magnesium/potassium hydroxide) leads to a decrease in leachate $\mathrm{pH}$ to below pH 8 independently of the ANC property of the waste (see Fig. 4). According to practical testing, a neutralization capacity around $3 \mathrm{~mol} \mathrm{H}^{+} / \mathrm{kg}$ at $\mathrm{pH} 5$ can be seen as having a high resistance to $\mathrm{pH}$ change (actually a neutralization potential of $1 \mathrm{~mol} \mathrm{H}^{+} / \mathrm{kg}$ at neutral $\mathrm{pH}$ range also often indicates that the waste is not sensitive to undergo changes to acidic $\mathrm{pH}$ range). 
- For evaluation of actual risks also information of the leachability of metals and DOC is needed. Furthermore, the leachability of compounds and subsequent ANC values are important input data in geochemical modelling, especially if long-term risks need to be evaluated.

- If the waste material is not significant in the landfill mass, the determination of ANC can be narrowed to a few target $\mathrm{pH}$ values (e.g. at neutral $\mathrm{pH} 7-8$ and/or at low $\mathrm{pH}$ value around $\mathrm{pH} 4$ ). The $\mathrm{pH}$ values of interest will depend on the external conditions (e.g. influence from other disposed waste materials).

\subsection{Critical wastes and waste properties with respect to ANC}

Wastes produced in significant amounts or wastes with high metal content (e.g. stable non-reactive hazardous waste) to be disposed on a nonhazardous landfill are typical examples of wastes for which ANC data are needed. Examples of such wastes are slag and ashes from energy production and dusts and sludges from metallurgical processes. For some waste types (e.g. coal fly ash) testing might not be needed if reliable results from similar materials are available.

The overall target in the waste management of single waste streams is to find the waste form and conditions where the leachability of harmful substances can be minimized. The target $\mathrm{pH}$ value is usually waste-specific. A special challenge is wastes containing several substances (generally metals) with different $\mathrm{pH}$ leaching behaviour (i.e. different $\mathrm{pH}$ ranges for minimum leachability of substances, see Fig. 1 and Table 1). For these types of waste, identification of a specific target $\mathrm{pH}$ is often a compromise taking into account the acceptance levels for specific substances.

A specific group of waste is alkaline ashes containing un-reacted lime (e.g. ashes from flue gas treatment containing an excess of calcium hydroxide). The calcium hydroxide is highly reactive and will control the initial $\mathrm{pH}$. Carbonation reactions of calcium hydroxide will probably occur within in a few months if the lime particles are in contact with air. This will lead to a $\mathrm{pH}$ decrease in the leachate of the waste. Here, testing of the leaching behaviour ranging from its own $\mathrm{pH}$ to down to $\mathrm{pH} 8$ is needed for the evaluation of waste acceptance of this waste in the long term.

Wastes with a low buffer capacity (e.g. ANC below $0.2 \mathrm{~mol} / \mathrm{kg}$ at $\mathrm{pH}$ 5) are easily affected by the surrounding conditions. For these wastes, especially those containing heavy metals, the influence of change in $\mathrm{pH}$ conditions needs to be evaluated to ensure that releases from the waste is acceptable in the case of a change in $\mathrm{pH}$ conditions in the long term. ANC testing is especially needed in the case where the waste is disposed in contact with other waste materials. A typical example is treated con- 
taminated soil, where buffering compounds are removed owing to treatment (e.g. washing, combustion processes).

For sulphide-containing wastes, ANC data are always to be required if the sulphide content exceeds 0.1 weight $\%$. The critical sulphide sulphur content depends on the content of the neutralizing compounds.

\section{References}

Astrup, T. 2004. Characterization of Leaching from Waste Incineration AirPollution-Control Residues. Ph.D. Thesis, March 2004. Environment \& Resources DTU, Technical Univeristy of Denmark.

Astrup, T., Jakobsen, R., Christensen, T.H., Hansen, J.B., Hjelmar, O. (2006), Assessment of long-term $\mathrm{pH}$ developments in leachate from waste incineration residues, Waste Management \& Research, Vol. 24, No. 5, 491-502

Baciocchi, R., Costa, G., Polettini, A., Pomi. R., 2008. An insight into the effect of accelerated carbonation on metal release from incinerator ash. Presented in. Proc. ACEME08, $2^{\text {nd }}$ International Conference on Accelerated Carbonation for Environmental and Materials Engineering, Rome, Italy, 13 October 2008.

Bendz, D., M. Arm, P. Flyhammar, G. Westberg, K. Sjöstrand, M. Lyth and O. Wik, Projekt Vändöra: En studie av långtidsegenskaper hos vägar anlagda med bottenaska från avfallsförbränning, 2006, Värmeforsk, 964.

Council Directive 1999/31/EC of 26 April 1999 on the landfill of waste. Official Journal, L 182, 1-19.

Council Decision 2003/33/EC of 19 December 2002 establishing criteria and procedures for the acceptance of waste at landfills pursuant to Article 16 of and Annex II to Directive 1999/31/ EC. Official Journal L 11 27-49. http://europa.eu.int/eur-lex/en/dat/2003/ 1011/101120030116en00270049.pdf.

CEN/TS 14429:2005. Characterization of waste. Leaching behaviour tests. Influence of $\mathrm{pH}$ on leaching with initial acid/base addition

CEN/TS 14997:2006. Characterization of waste. Leaching behaviour tests.
Influence of $\mathrm{pH}$ on leaching with continuous $\mathrm{pH}$-control

Directive 2006/21/EC of the European Parliament and of the Council of 15 March 2006 on the management of waste from extractive industries and amending Directive 2004/35/EC. Official Journal L 102 15-33.

Ehrig . H.J. 1983. Quality and Quantity of Sanitary Landfill Leachate. Waste Management \& Research, Vol. 1, No. 1, 53-68 (1983)

Eglinton, M. in: P.C. Hewlett (Ed.), Resistance of concrete to destructive agencies, Lea's Chemistry of Cement and Concrete, 4th Edition, Arnold, London, 1998, pp. 299-342.2

Elert, M., Eliaeson, K., Strandberg, J., Nilsson, S., Wadstein, E., Enell, A., Berggren Kleja, D. and Gustafsson, J. P. (2008) "Föroreningsspridning - Tilllämpning och utvärdering av metoder - huvudrapport". Naturvårdsverket, 5834 http://www.naturvardsverket.se/ Documents/publikationer/978-91-6205834-0.pdf.

El-Fadel, M., Findikakis, A.N., Leckie, J.O. (1997). Environmental impacts of solid waste landfilling. J.o. Environ. Managem. 50:1-27.

Global Acid Rock Drainage (GARD) Guide 2009. The International Network for Acid Prevention (INAP). available on the web at: http:// www480.pair.com/aturner/gardwiki/ Hjelmar, O., Holm, J. \& Crillesen, K.: Utilisation of MSWI bottom ash as sub-base in road construction: First results from a large scale test site. Journal of Hazardous Materials A139, 2007, pp. 471-480.

IPCC report. Climate Change 2001: Impacts, Adaptation, and Vulnerability : Contribution of Working Group II to the Third Assessment Report of the In- 
tergovernmental Panel on Climate Change. By James J. McCarthy, Intergovernmental Panel on Climate Change Working Group II., Osvaldo F. Canziani. Contributor James J. McCarthy. Edition: 2, illustrated. Published by Cambridge University Press, 2001

Jambor, J.L., Dutrizac, J.E. ja Raudsepp, M. 2005. Neutralization potentials of some common and uncommon rocks, and some pitfalls in NP measurements. 12th Annual British Columbia MEND ML/ARD Workshop, 30.11.-1.12.2005.

Kaartinen, T. 2004. Sustainable final disposal of residues from municipal solid waste pretreatment in a future landfill. Diploma thesis, Helsinki University of Technology, Department of civil and environmental engineering

Kwong, Y.T.J. 1993. Prediction and prevention of acid rock drainage from a geological and mineralogical perspective CANMET, MEND report 1.32.1, Energy, Mines and Resources, $47 \mathrm{~s}$.

Laine-Ylijoki, J., Syrjä, J-S., Wahlström, M. 2004. Biodegradability testing of the municipal solid waste reject. Nordic Innovation Centre.Norway, Report NT TR 560,21 p + App.

Laine-Ylijoki, J., Kaartinen, T., Syrjä, J., Wahlström, M. Oberender, A., Hansen, J.B., Hjelmar, O., Suèr, P., Lyth, M., 2005. Test for DOC-leaching from waste materials . Nordic Innovation Centre. Norway, Report NT TR 582, $22 \mathrm{p}+$ App.

Lawrence, R.W. \& Scheske, M. 1997. A method to calculate the neutralization potential of mining wastes. Environmental Geology 32 (2) September 1997

Lehmann, N.K.J., Hansen, J.B, Wahlström, M., Fällman, A.-M. \& Hjelmar, O. 2000. Influence of critical test conditions on the results of $\mathrm{pH}$-dependent leaching tests. Nordtest, NT TECHN REPORT 466, 98 p.

Meima, J.A., van Zomeren, A. \& Comans, R.N.J. 1999. Complexation of
Cu with Dissolved Organic Carbon In Municipal Solid Waste Incinerator Bottom Ash Leachates, Environ. Sci. Technol. 1999 (vol. 33), 1424-1429. Paktunc, A.D. 1999. Discussion of “A method to calculate the neutralization potential of mining wastes" by Lawrence and Scheske. Environmental Geology 38 (1) June 1999

Piantone, P. 2008. Acid Mine Drainage: Speciation of sulphur and acid production. Draft (not published) van der Sloot, H.A., van Zomerena, A., Meeussen, J.C.L. \& Seignette, P., Bleijerveld, R. 2007. Test method selection, validation against field data, and predictive modelling for impact evaluation of stabilised waste disposal. Journal of Hazardous Materials 141 (2007) 354-369

van der Sloot, H. A., Dijkstra, J., Hjelmar, O. Spanka, G., Bluyssen. P., Giselsson. S. 2008. Evaluation of a horizontal approach to assess the possible release of dangerous substances from construction product in support of requirements from the Construction Products Directive, Draft TR2 Report Impact Soil, Surface Water, Ground Water and Indoor Air

Sverdrup, H.U. 1990. The Kinetics of Base Cation Release Due to Chemical Weathering. Lund, University Press, Lund 1990.

Yan, J., C. Baverman, L. Moreno and I. Neretnieks, Evaluation of the timedependent neutralising behaviours of MSWI bottom ash and steel slag. Science of the Total Environment, 1998. 216(1-2): p. 41-54.

Stegemann, J., Buenfeld N.R. 2002. Prediction of leachate $\mathrm{pH}$ for cement paste containing pure metal compounds. Journal of Hazardous Materials B90 (2002) 169-188Boels, D.

Stumm, W., Morgan J.J., (1995) Aquatic Chemistry-Chemical equilibria and rates in natural waters, $3^{\text {rd }}$, Wiley Interscience Publication, 1022p. 



\section{Swedish summary}

Målsättningen med EUs deponeringslagstiftning är att avfallet omhändertas på ett säkert sätt i ett långt perspektiv. Rådets beslut 2003/33/EG, som anknyter till EUs deponeringsdirektiv 1999/31/EG ställer allmänna krav på grundläggande information om avfallets karaktär för att förbättra kunskapen om avfallets beteende på en deponi. På basen av denna information bestäms kraven på behandling av avfallet. Ett informationskrav är bestämning av avfallets neutraliseringskapacitet (acid neutralization capacity, ANC) vilket ger uppgifter om avfallets långsiktiga beteende. ANC-egenskapen ger både information om själva avfallets beteende och viktig insikt i omgivningens inverkan på materialet i en deponimiljö (t.ex. orsakad av samverkan mellan olika material och lakvatten).

Avfallsmassan på en deponi skall vara och hållas neutral (pH 7-8) för att undvika eventuella negativa effekter på processer i deponin, deponikonstruktionen och i deponins omgivning. Sura eller alkaliska lakvatten kan uppträda när de neutraliserande effekterna (t.ex. mineraler) inte kan neutralisera syra eller bas som uppkommit vid kemiska förändringar hos avfallet (t.ex. vid sulfidoxidering, anaerobisk eller aerobisk rötning av organiska ämnen) eller genom externa effekter (t.ex. sura regn eller karbonatiseringsreaktioner där speciellt kalcium hydroxid reagerar med luftens koldioxid). Ökad utlakning av metaller och organiskt material och nedsatt funktionalitet $\mathrm{i}$ deponikonstruktioner kan orsakas av både lågt och högt $\mathrm{pH}$ värde $\mathrm{i}$ lakvattnet.

Denna rapport ger bakgrundsinformation om betydelsen av ANC egenskapen och dess koppling till hållbara deponeringsförhållanden. Avsikten med rapporten är också att ge en vägledning för hur ANC resultaten skall tolkas. Dessutom innehåller rapporten en översikt om kritiska avfall och parametrar som påverkas av avfallets ANC egenskap. ANC-egenskapen kan inte tolkas som en enskild parameter. Resultaten från ANCtestning måste bedömas på basen av deponeringsförhållandena (inklusive övrigt deponerat avfall) samt också på basen av risker för uppkomsten av sura vatten, vilket orsakas av kemiska eller biologiska reaktioner i avfallet. Rapporten belyser speciellt betydelsen av karbonatiseringsprocessen vid bedömning av långtidsegenskaper hos avfall (t.ex. slagg och askor från energiproduktion). 